はじめに

甲状腺㴦の $90 \%$ 近く古占める分化密は自然経過が長 い委の成多く，また手術成績は非常に良好で予後の い癌として知られている。手術は他藏器の癌の場合と

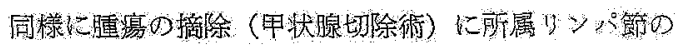
郭清（頸部郭清術）を拼党る凯であるが，和となしい

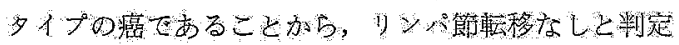

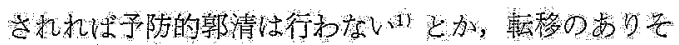

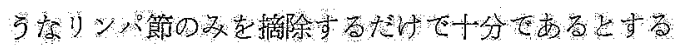

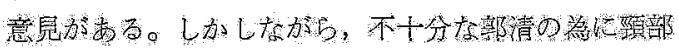

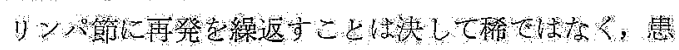

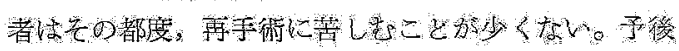

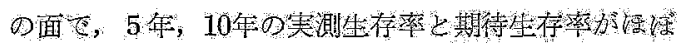

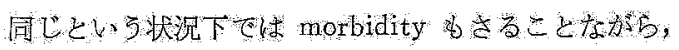
morbidity 老重視することはあな放ち間違いではなか力 ろう。

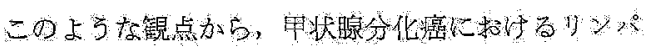
節新清は最小限どの範囲をで行う必要があるかについ

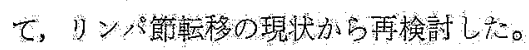

\section{対象および方法}

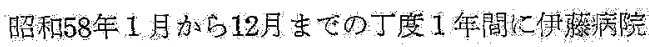

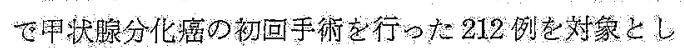

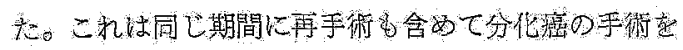
行った総数 247 例の85.8\%にあたる。性别は男性20例

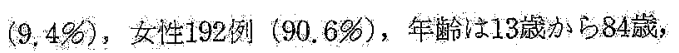

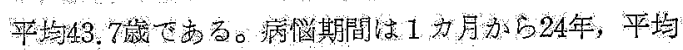

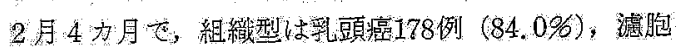

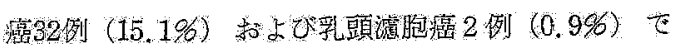
苏った。

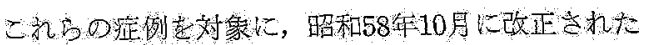

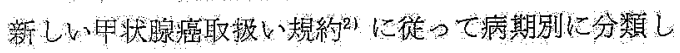

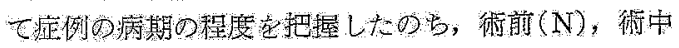

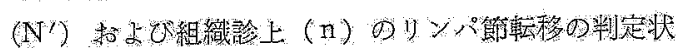

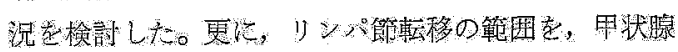

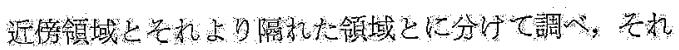

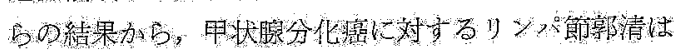

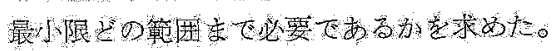

\section{結 果}

\section{I. 新し6果将腺癌取投し规約に基づく病期分類}

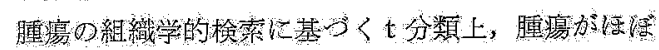
一㑡葉に限局していて R1 郭清に上って根治手術が期

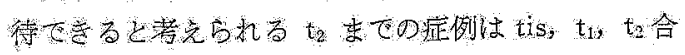
わせて140例で全体の66\%を占めていた（圆 1)。

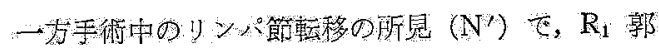

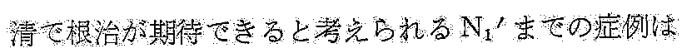

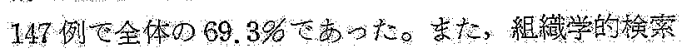
に基づくリンパ節転移の所見でも $\mathrm{n}_{1}$ をでの症例は138

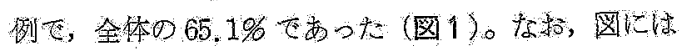
示していないが，紌前のリンパ節転移の所見で，门》 


\section{日本外科系連合学会諲 第12号}

ハ節転移なしを判定した $\mathrm{N}_{0}$ は187 例 $(88.2 \%)$ て，

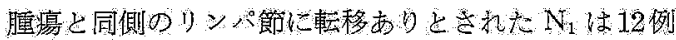
(5.7\%) のみであった。

\section{N, N' こついての評価}

$\mathrm{t}$ 分類に関係なく，術前 $(\mathrm{N})$ 及び術中 $\left(\mathrm{N}^{\prime}\right)$ のリ

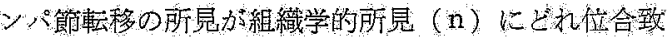
している为について検討した。これは，212例的 ち, local dissection 以上の郭清を行った155例老対象 ¿lto

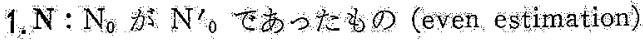

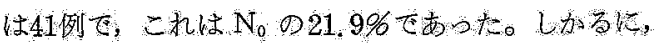

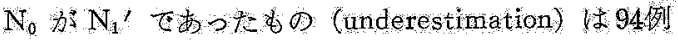

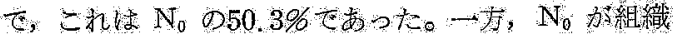
学的に寻 $\mathrm{n}_{0}$ であったものは 29 例 $\left(\mathrm{N}_{0}\right.$ の15.5\%) で

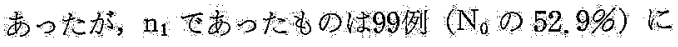

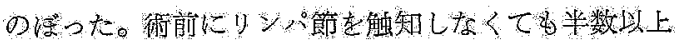

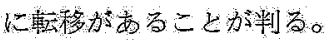

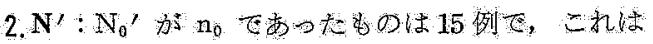

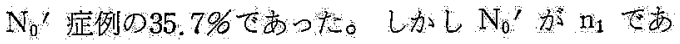

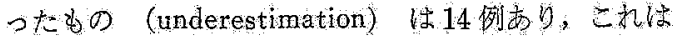

病期 矮 $\left(\mathrm{C}, \mathrm{A}^{2}, \mathrm{n}\right)$
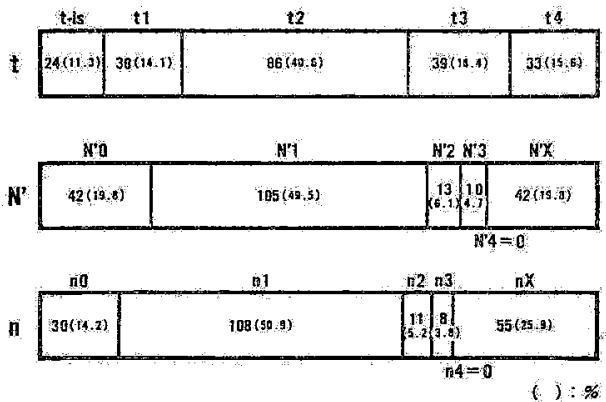

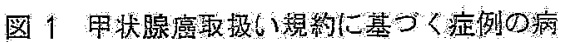
期分類

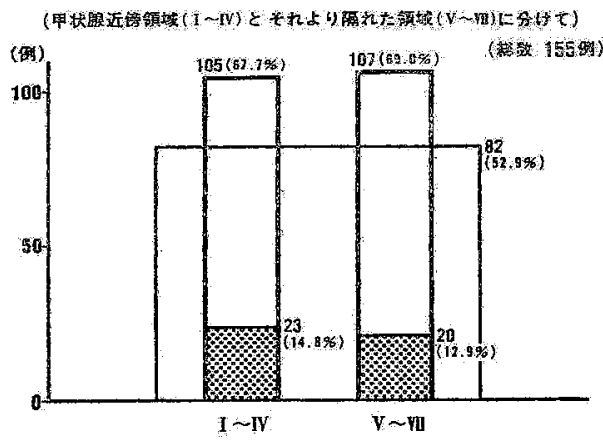

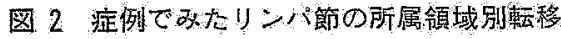
陽性率

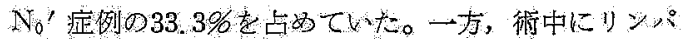

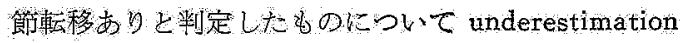

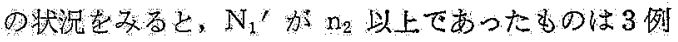

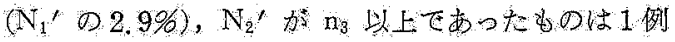
$\left(\mathrm{N}_{2}{ }^{\prime}\right.$ の7.7\%) にす巳゙加た。即与, 乎術中にり义

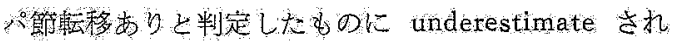

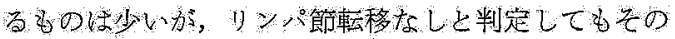

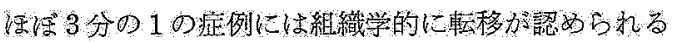
訳でり，(予防的) 新清の要否老判断する根拠とし て $\mathrm{N}_{0}{ }^{\prime}$ 加正当であるとするにはな打检討の余地场す 35.

\section{III.リンパ節の所属領域别転移陽性率}

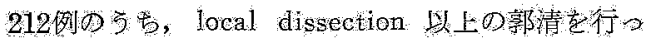
た I55例定効象にし，リンパ節の学属領域を甲状腺近 傍領域 $(\mathrm{I} \sim \mathrm{V})$ とそれより隔れた領域 $(\mathrm{V} \sim \mathrm{Vil})$ と

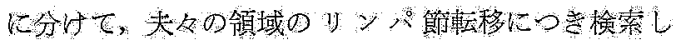

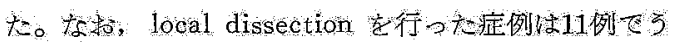

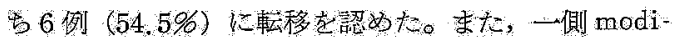
fied neck dissection (以下 mnd と略す) を行った 124例中101例 (81.5\%) に，而側 nnd 老行った20例

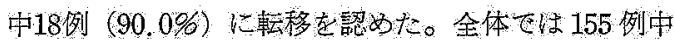
125例 $(80.6 \%)$ 中転移陽性を志った。

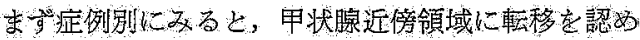

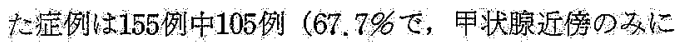

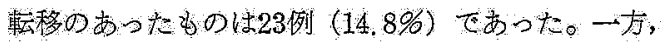

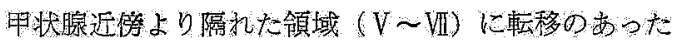

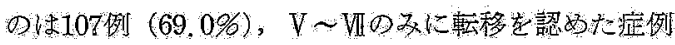

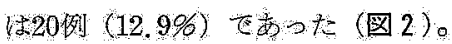

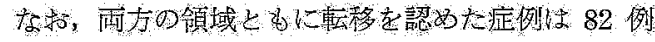
(52.9\%) てあった。

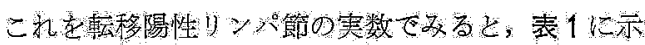

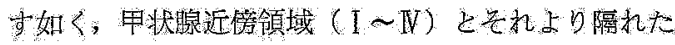
領域（V〜价）では，䎐移陽性リシメ゚節数は 453 個と

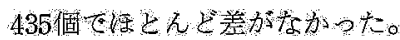

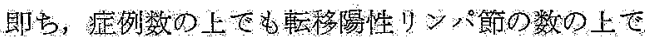
も，甲状腺近傍領域とそれより隔れた領域とでは転移

表 1 リンパ節の所属領域別転移陽性率 (リンパ節数別)

\begin{tabular}{|c|c|c|c|}
\hline 領 域 & リ 回 收 & $\begin{array}{l}\text { 転移陽性 } \\
\text { リンハハ愠数 }\end{array}$ & $\%$ \\
\hline $\mathrm{I} \sim \mathrm{IV}$ & 1,139 個 & 453.個 & 39.8 \\
\hline$V \sim$ VII & 2,715個 & 435個 & 16.0 \\
\hline 評 & 3;854 俔 & 888個 & 23.0 \\
\hline
\end{tabular}


第 9 回学術集会シンポジウム

表 2 腫痀の占居部位と領域別リンパ節転移 との閶係

(占居部位が $1 / 3$ 萧以下のもので mndを行った症例について)

\begin{tabular}{|c|c|c|c|}
\hline 占居部位 & 症例数 & $\mathrm{I} \sim \mathrm{IV}$ 杄城 & $\mathrm{V} \sim \mathrm{VII}$ 钼棫 \\
\hline 上 $1 / 3$ & 18 & $12(66.7)$ & $14(77.8)$ \\
\hline 中 $1 / 3$ & 31 & $22(31.0)$ & $20(64.5)$ \\
\hline F $1 / 3$ & 19 & $9(47.4)$ & $7(36.8)$ \\
\hline st & 68 & $43(63.2)$ & $41(60.3)$ \\
\hline
\end{tabular}

表 3 腫癁の占居部位と領域別リンパ節転移 との関係

\begin{tabular}{|c|c|c|c|c|}
\hline \multirow[b]{2}{*}{ 占居部位 } & \multicolumn{2}{|c|}{ I IV 颃弶 } & \multicolumn{2}{|c|}{ 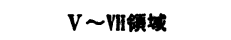 } \\
\hline & リ回 珻 & リンバ籍数 & リ国紧 & 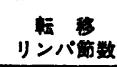 \\
\hline 上 $1 / 3$ & 99 & $42(12.1)$ & 307 & $38(12.4)$ \\
\hline 中 $1 / 3$ & 146 & $50(34.2)$ & 434 & $56(12.8)$ \\
\hline F $1 / 3$ & 105 & $34(32.4)$ & 240 & $28(11.7)$ \\
\hline it & 350 & $126(36.0)$ & 981 & $122(12.4)$ \\
\hline
\end{tabular}

の状況はほとんど差がないことが明らかである。

\section{$\mathrm{N}$ 、腫埸の占居部位とリンパ節転移}

腫湟の甲状腺内占居部位が片葉の 3 分の 1 以下で, 一側又は両側の mnd を行った68例について, 腫瘍の 占居部位によって甲状腺近傍領域と，それより隔れた 領域との間にリンパ節転移の上で差があるか否かを検 討した。

症例の上での転移をみると, 表 2 に示す如く, 上 3 分の 1 では，むしろ甲状腺より隔れた領域に多く，ま た，中・下夫々の部位でも，甲状腺近傍領域との間に ほとんど差がみられなかった。また同様に，回収リン パ節の中の転移陽性リンパ節数では, 表 3 に示すよう に，甲状腺近傍領域とそれより隔れた領域とで，転移 リンパ節数にほとんど差がなかった。

\section{考 察}

甲状腺分化癌のほとんどは生物学的におとなしい性 質でありその手術予後は非常に良好である。その為
に，手術術式の比較検討を生存率をもとに行うこと自 体むつかしいことが多く，患者の立場から考えれば， mortality は勿論であるが morbidity む非常に重要 な因子であるものと考劣られる。手術中にリンパ節転 移なしと判定したものには（予防的）郭清を行わない という意兒もあるが”，術中に転移なしと判定しても 郭清してみるとその 3 分の 1 の症例に組織学的に転移 が証明されることを考えると，郭清の要否を判断する 根拠として術中のリンパ節の所見は適切ではないと考 えるべきであろう。

癌の診断して手術する患者にはルーチンに郭清を行 うとなれば，どの範囲まで行うかが問題となるが，実 際には最小限必要な範囲が知りたい。甲状腺癌取扱い 規約では, 原発腫瘤と同側の所属リンパ節 I 〜 VIIよ び反対側 III のリンパ節を郭清するものを $\mathrm{R}_{1}$ 郭清と規 定しているが，我々の症例では， $\mathrm{t}$ 分類でも $\mathrm{n}$ 分類で も約 3 分の 1 の症例が $R_{1}$ 郭清を行学ば根治が期待て きる病期のものであった。更にリンパ節転移の広がり 状況からみると, 甲状腺近傍領域 $(I \sim N)$ と，それ より隔れた領域（V〜VI）とでほとんど差がみられな かった。このようなことを考光併せると，根治手術を 行う為には甲状腺近傍領域のみならず，それより隔れ た V〜V領域をも系統的に郭清する $R_{1}$ 郭清が，必要 最小限の郭清術式としてとられるべきてあると考えら れる。

\section{おわりに}

術中のリンパ節転移の所見が郭清の要否の判定根拠 とならないこと, 及び甲状腺近傍領域とそれょり隔れ た領域とでリンパ節転移の状況にほとんど相違がない こと,などから, 甲状腺分化癌に対する必要最小限の リンパ節郭清として $\mathrm{R}_{1}$ 郭清を行う必要があるものと 考えられた。

\section{文 献}

1) 牧内正夫 : 癌のリンパ節郭清をどうするか一一甲 状腺癌, 臨外 $35: 725-731,1980$.

2 ) 甲状腺外科検討会編：甲状腚癌取扱、規約，金原 出版, 東京, 第 2 版, 1983. 


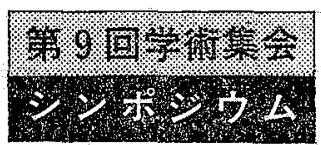

$S-I-19$
昭和59年 8 月 3,4 日（金, 土）

ロイヤルN C B 会館

\title{
諸臓器癌におけるリンパ節郭清法一C 群
}

\author{
甲状腺癌のリンパ節郭清法
}

信州大学第 2 外科

宾 川 信

はएक⿺

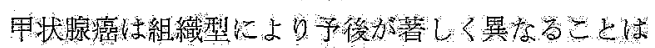

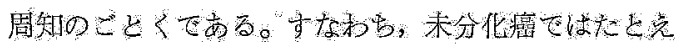

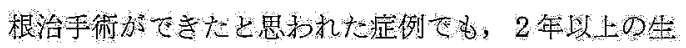

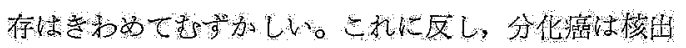

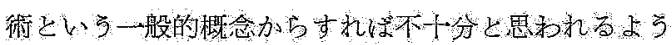

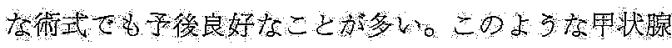

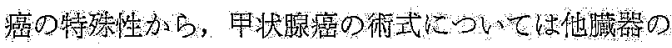

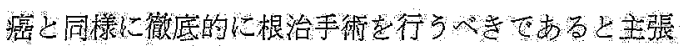

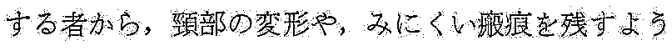

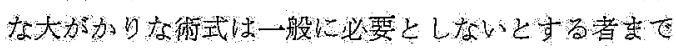

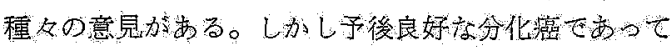
3. 癌切除・郭清为十分でな⿰力口一 non-eurative

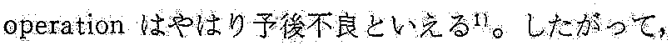

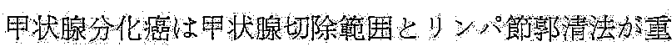

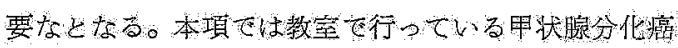
の狱式とリ 急。

\section{I、甲状腺切除符国}

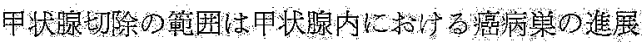

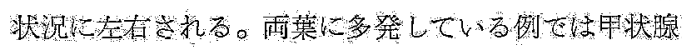

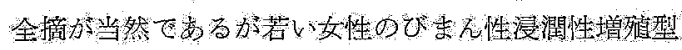

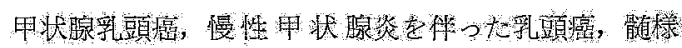

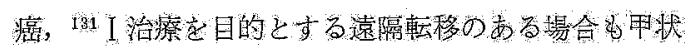

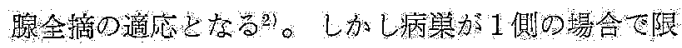

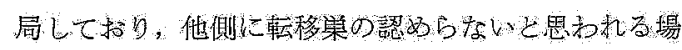

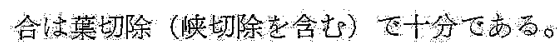

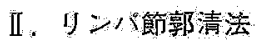

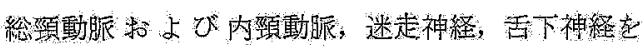

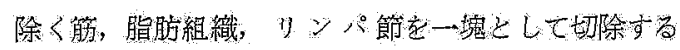

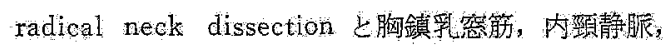
剧神絽就已温存する nodified neck dissection

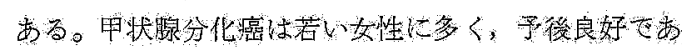

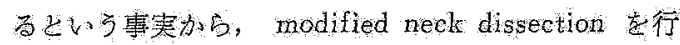

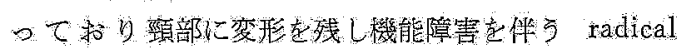

neck dissection 1 , 通常の症例をは必要ないと考

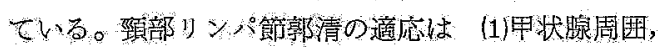

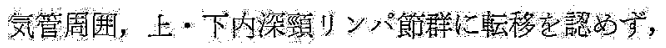

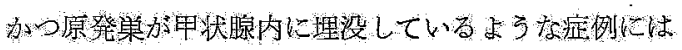

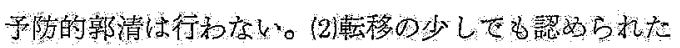

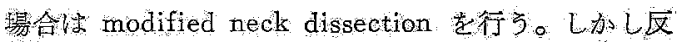

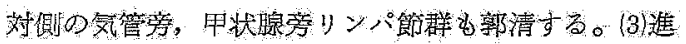
展㿋には車側 modified neck dissection を行 $5 。(4)$.

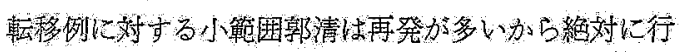
bts

III. リンパ節転移の部位別触知率

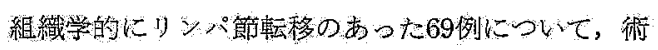

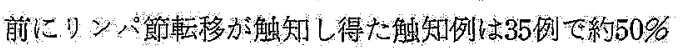

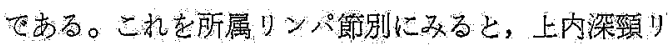

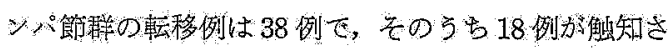

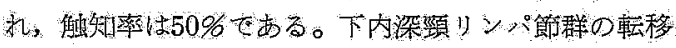

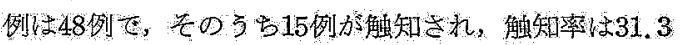

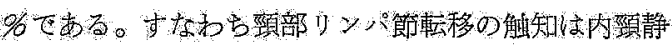

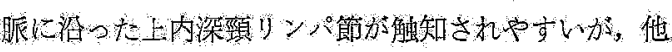

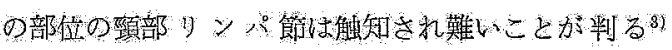
(表 1)。

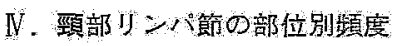

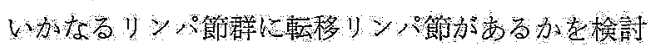

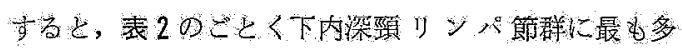

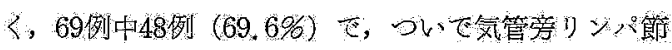

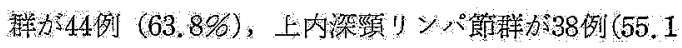

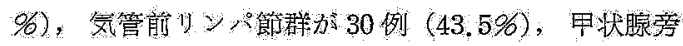

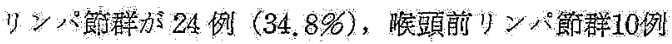

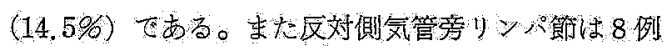
(11.6\%), 顠下

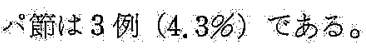

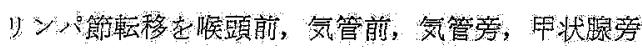

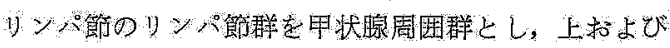

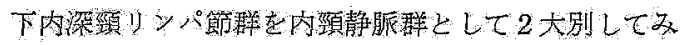
3飞，甲状腺国国群02 
表 1 リンパ節転移の部位別触知率

\begin{tabular}{|c|c|c|c|}
\hline 所属リンパ節 & $\begin{array}{l}\text { 転移例 } \\
(69 \text { 例) }\end{array}$ & $\begin{array}{l}\text { 触知例 } \\
\text { (35例) }\end{array}$ & 触知率 \\
\hline 喉 頭 前 & 10例 & 0例 & $0 \%$ \\
\hline 気 管 前 & 30 & 2 & 6.7 \\
\hline 気 管 旁 & 44 & 1 & 2.3 \\
\hline 反対側気管旁 & 8 & 0 & 0 \\
\hline 甲状腺旁 & 24 & 0 & 0 \\
\hline 上内 深 頸 & 38 & 19 & 50.0 \\
\hline 下 内 深 頸 & 48 & 15 & 31.3 \\
\hline 外 深 頸 & 3 & 0 & 0 \\
\hline
\end{tabular}

（注：表中の例数はのべ数）

表 2 リンパ節転移の頻度（69転移例）

\begin{tabular}{|c|c|c|c|c|}
\hline 所属リンパ節 & $\begin{array}{l}\text { 転移例 } \\
\text { の゙数 }\end{array}$ & (\%) & & \\
\hline 喉頭前 & 10 & $(14.5)$ & \multirow{5}{*}{$13(18.8)$} & \multirow{7}{*}{$47(68.1)$} \\
\hline 気管前 & 30 & (43.5) & & \\
\hline 気管傍 & 40 & $(63.8)$ & & \\
\hline 反対側気管傍 & 存 8 & (11.6) & & \\
\hline 甲状腺傍 & 24 & $(34.8)$ & & \\
\hline 上内深頸 & 34 & $(55.1)$ & \multirow{2}{*}{$9(13.3)$} & \\
\hline 下内深頸 & 48 & $(69.1)$ & & \\
\hline 外深頸 & 3 & $(4.3)$ & & \\
\hline 䫑下 & 5 & ( 7.2$)$ & & \\
\hline
\end{tabular}

(18.8\%), 内頸静脈リンパ節群のみのものは 69 例中 9 例 (13\%), 両群にわたるもの 47 例 $(68.1 \%)$ とな り，両群に同時に転移を有する例が大多数を占めてい る。すなわち, 甲状腺周囲群あるいは内頸静脈群のみ に転移がみられることは稀でほとんどの転移はすでに 内頸静脈群にまでおよんでいることが判る3)。

V. Thyroid lymphangiography からみたリンパ 節造影時間

油性の造影剂ポピオドールを甲状腺組織に直接注入 し，それを経時的に観察して甲状腺からリンパ管(節) が造影されるまでの時間をX線撮影を行って検討した (図 1)。I の喉頭前リンパ節では28例中 17 例が 1 時間 以内に造影され，II の喉頭前リンパ節では28例中26例 III気管傍りンパ節では28例中22例, Vの上内深頸り ンパ節では28例中27例， Иの下内深頸リンパ節では28 例の全例かいずれむ 1 時間以内に造影されている。以 上のIからりまでのリンパ節群では早期に造影される ことが示された。またりの外深頸りンパ節の造影され る例は28例中 5 例と少く, かつ造影時間も 1 時間以後 であり, 叫の㶦下リンパ節も28例中11例と少く造影さ れる時間む遅れている。以上の事実より, 甲状腺周团
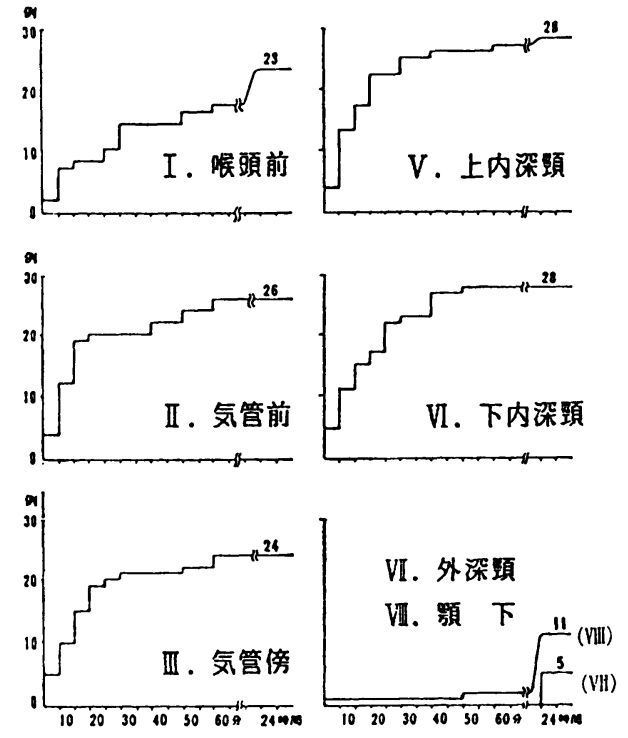

図 1 Thyroid lymphography によるリンパ節 造影䓵間（28例）

および内頸静脈に沿うリンパ節群ではその大部分が 1 時間以内に造影され，しかも両者間に時間的差がない ことが判明した。このことは先に述べた転移リンパ節 において, 甲状腺周囲リンパ節群と内頸静脈群のリン パ節群がほぼ同時にリンパ節転移が認められた事実を 立証するものと考えられる。一方, 外深頸りンパ節群 ならびに顎下リンパ節群ではそれぞれリンパ節の造影 される例も少なく，また造影時間も遅れていることが 判明しだ)。

$\mathrm{V}$, リンパ節郭清法とリンバ節再発

頸部根治手術を行った症例の再発は $9.4 \%$ てあり, 小範囲郭清を行った症例のそれは $15.4 \%$ あっって,ど こかにリンパ節転移を認めた場合は小範囲郭清にとど まらず頸部根治手術を行うべきことを示している。

VII. 甲状腺癌の占居部位とリンパ節転移

癌が甲状腺の上部に存在する場合は, 上内深頸りン パ節群に $72.7 \%$ ，また顎下部リンパ節群は $13.6 \%$ に転 移リンパ節が認められた。このことは甲状腺上部に癌 が存在する場合は䫛下部リンパ節群まで郭清する必要 があることを示している。癌か中部にある場合は気管 旁リンパ節群に 8 例中 8 例 (100\%) の全例に転移り ンパ節が認められた。癌が下部にある場合は下内深頸 リンパ節群に57.9\%に転移リンパ節が認められ，上内 深頸リンパ節群には $21.1 \%$ と癌の占居部位によってり ンパ節転移部位は異ることが認められた。また腺葉全 体を占めるような場合は外深頸・影下リンパ節群にい 
日本外科系連合学会誌 第12号

表 3 原発腫瘤の甲状腺内占居部位とリンパ節転移の広がり

\begin{tabular}{|c|c|c|c|c|c|}
\hline 所属リンパ節 & $\begin{array}{l}\text { 上部 } \\
22 \text { 例 }\end{array}$ & $\begin{array}{l}\text { 中部 } \\
8 \text { 例 }\end{array}$ & $\begin{array}{l}\text { 下部 } \\
\text { 19例 }\end{array}$ & $\begin{array}{l}\text { 全体 } \\
\text { 20例 }\end{array}$ & $\begin{array}{l}\text { 合計 } \\
69 \text { 例 }\end{array}$ \\
\hline 㗋 頭 & $3(13.6)^{96}$ & $1(12.5)^{96}$ & $2(10.5)^{\% 6}$ & $4(20.0)^{96}$ & 10 \\
\hline 気 管 & $8(36.4)$ & $5(62.5)$ & $7(36.8)$ & $10(50.0)$ & 30 \\
\hline 気 管 竝 & $15(68.2)$ & $8(100.0)$ & $10(52.6)$ & $11(55.0)$ & 44 \\
\hline 反対側気管咅 & $1(4.5)$ & 0 & $2(10.5)$ & $5(25.0)$ & 8 \\
\hline 甲状腺旁 & $6(27.3)$ & $2(25.0)$ & $4(21.1)$ & $12(60.0)$ & 24 \\
\hline 上内深项 & $16(72.7)$ & $7(87.5)$ & $4(21.1)$ & $11(55.0)$ & 38 \\
\hline 下 内 深 頸 & $15(68.2)$ & $7(87.5)$ & $11(57.9)$ & $15(75.0)$ & 48 \\
\hline 外 深 项 & $1(4.5)$ & 0 & 0 & $2(10.0)$ & 3 \\
\hline 顎 & $3(13.6)$ & 0 & 0 & $2(10.0)$ & 5 \\
\hline
\end{tabular}

（注：転移例はのべ数）

表 4 再手術14例におけるリンパ節転移

\begin{tabular}{cccc|cc}
\hline 転 & 移 & 嵒 & 位 & 例 & 数 \\
\hline 上 & 内 & 深 & 頸 & $10 \%$ & $(71.4)$ \\
下 & 内 & 深 & 頸 & 4 & $(28.6)$ \\
外 & \multirow{2}{*}{ 深 } & 頸 & 1 & $(7.1)$ \\
顎 & & & 下 & 3 & $(21.4)$ \\
\hline
\end{tabular}

ずれも10\%に転移リンパ節が認められたことは,この ような進展した癌にはやはり広範囲郭清の必要性を物 語っているる（表 3）。

\section{VII. 再手術例におけるリンパ節输移部位の梌討}

靧部根治手術を行った 170 例のうち, 再手術を行っ た14例のリンパ節転移部位を検討すると, 上内深頸り ンパ節が10例，下内深頸リンパ節が 4 例，影下部リン ハ節が 3 例，外深頉リンパ節が 1 例て，いずれも進行 した癌に対する郭清不十分であったことを意味するも のと思われる3（表 4 ）。

\section{X. 維隔郭清の適応}

縱隔郭清については通常な甲状腺癌においては䫓部 を進展した体位て銷骨上窩, 胸骨上縁からの郭清で十 分と考えられているが, 髄様癌, 甲状腺の下部に癌が 存在している場合で，気管旁，下内深頸の下方のリン パ節群に転移が認められる場合は縱隔の郭清も考慮し なければならない。教室では，断眉撮影，CT スキャ ンの $4 \mathrm{~mm}$ スライス幅で連続スキャン, ${ }^{201} \mathrm{~T} l$ シンチグラ フィーあるいは1 ${ }^{131}$ I シンチグラフィーで少しでも転移 リンパ節が疑がわれる場合は縦隔郭清を行っている。

$X$ ．两側頙部部清時の上皮小体のとり扱い

両側頸部郭清を十分に行了と上皮小体機能低下は避 けられない事実である。したがって教室では此較的健
側と思われる側の上皮小体，特に上上皮小体を検索 し，支配動脈を温存することが困難と思われる症例に は上皮小体 1 個以上を摘出し, 生理的食塩水につけて 甲状腺部の手術終了と共に，その上皮小体を細切し， 前腕筋内に移植している4。。こにより永久性上皮小 体機能低下症は起こっていない。

$$
\text { まとめ }
$$

1.甲状腺周囲, 気管周囲, 下内深頸リンパ節群な どに転移を認めず，かつ原発巣が甲状腺内に埋没して いる症例には予防的郭清は行わない。

2. リンパ節郭清は一般的に胸鎖乳突筋, 副神経を 温存し，ときには内頸静眽む温存する modified neck dissection を行う。しかし，反対側の気管旁，甲状腺 产リンパ節群も郭清する。

3. 進展癌には両側の modified neck dissection を行う。その時には，できるだけ健側の上皮小体を深 し，一個以上前腕筋内に細切し自家移植する。また $\mathrm{CT}, \mathrm{T} l$ スキャンなどで縱隔内にリンパ節転移が疑が われる場合は緥隔郭清を行う。

4. 転移リンパ節の認められる症例には，小範囲郭 清は行わない。少くとも mndified neck dissection を行了。

\section{文 献}

1）宮川 信, 山本香列：甲状腺進行癌手術における 搌頭・気管の再建，䠛外， $38: 469,1983$.

2）宮川 信, 降旗力男：甲状腺全摘とその後遺症, 日医新報， $2919 ： 48 ， 1980$ 。

3）佐藤趣夫：甲状腺癌りンパ節転移に関する研究, 信州医誌, $22: 107,1974$.

4）小林 克, 宮川 信: 甲状腺全摘時の上皮小体自 家移植の有用性，外科治療 $48: 648 ， 1983$ 。 


\title{
諸臓器癌におけるリンパ節郭清法一 $\mathrm{C}$ 群
}

$$
\mathrm{S}-\mathrm{I}-20
$$

\author{
甲状腺癌のリンパ節郭清法
}

\begin{tabular}{|c|c|c|c|c|c|c|c|c|c|}
\hline \multicolumn{10}{|c|}{ 岩手医科大学第 1 外科 } \\
\hline 佐々木 & & 純 & 多 & 田 & 隆 & \pm & 小 & 川 & 将 \\
\hline 加 藤 & 典 & 博 & 西 & 成 & & 忍 & 石 & 田 & 茂登男 \\
\hline 田 & & 博 & 森 & & 昌 & 造 & & & \\
\hline
\end{tabular}

\section{緒 言}

われわれは血行転移のない，根治可能な甲状腺分化 癌に対し，原則として甲状腺全摘と甲状腺癌取扱い規 約による $\mathrm{R}_{1}$ 郭清をしている。厳密に云えば， $\mathrm{R}_{1}$ に 加えて対側の下深頸リンパ節まで追加郭清している。

\section{部清方法}

郭清の順序は 1 ．まず喉頭前リンパ節を含めた甲 状腺全摘をやり，2．次に気管前ならびに左右旁気管 リンパ節を郭清し， 3 . 次に患側の上下ならびに外深 頸リンパ節を郭清し， 4. 最後に対側の下深頸リンパ 節を郭清する。広範なリンパ節転移がある時のみ, $\mathrm{R}_{2}$ 郭清を行なっている。一方リンパ節腫脹を認めない微 少癌は郭清しない。

副神経, 胸鎖乳突筋は残し, 内頸静脉もできる限り 残す modified neck dissection てある。この部清中 もっとも問題なのは気管前ならびに気管旁リンパ節の 郭清であ。この部位えの転移率は高く, 再発は気管 狭窄を来し, 死因につながり得る。しかし，ここを撤 底的に郭清しょうとすれば往々にしてテタニーと嗄声 を来す。われわれはこの部位の郭清法に工夫を重ね好 成績を挙げているので紹介する。

まずわれわれは自家製の特別な器械を二, 三使用し ている。頸静脉把持鉗子と小型の結禁糸輸送器と甲状 腺開創器で, 甲状腺開創器は右側頸部部清用と左側頸 部郭清用とある。

まずU字型皮虐切開を入れ，前頸筋を横断して開創 器をかけ大きく上下に開く，そして甲状腺を全摘す る。甲状腺を遊離する際，上上皮小体附近にはリンパ 節がないので, 甲状腺の表面被膜に近く剥離し, 少な
くとも健側の上上皮小体 1 個を周囲に脂肪組織をつけ て確実に残す。この様な細かい操作に当っては，われ われの改良した小型結禁糸輸送器が役に立つ, また上 皮小体か脂肪か判別しにくい組織があった時，われわ れが考案した簡単な迅速同定法で確認する。その組織 を帽針頭大に切り取り，オブジェクトグラスにのせ， 生理食塩水を一滴加え, カバーグラスで押し潰し, 無 染色のまま鏡検すると脂肪は透明度の高い粗大滴状物 の集合体としてみえるのに対し，上皮小体は䙓色顆粒 をもった密な細胞集団て，ところどころ脂肪滴が散在 しているものとしてみえるので簡単にその場で区別て きる。

次に反回神経を 2 本のピンセットを使って縦隔ので きるだけ深部まで遊離する。反回神経を甲状腺の下 方で求めるのは困難で, 損傷する危険があるが, 甲状 腺を全摘したあとであれば,この神経の堠頭侵入部は 既に露出しているので,この操作は安全, 容易にで る。この神経は麻痻し易いので,ピンセットで摑んだ り,テーピングしてひっぱったりしてはいけない（図 1)。

反回神経を後方に遊離避難せしめた後に気管前，な らびに左右の気管旁リンパ節を周囲の脂肪組織と共に 前方に剝す。そして胸腺の上部を下上皮小体を含め てこれら組織をでさるだけ縦隔側て止血鉗子をかけ て切除し, 切離縁は mattress suture て止血する。 切除標本の中に含亡れている下上皮小体を探し出し, もし癌に唚されていない様てあれば, 先程の迅速同定 法で確認し, 細切して胸鎖乳突筋内に移植する。下上 皮小体は発見が困難で, 癌に侵されていることもあ り，かつ無理に残そうとすればリンパ節の郭清がおろ そかになる（図2）。 


\section{日本外科系連合学会誌 第12号}

以後の操作は容易である。患側の上下ならびに外深 頸リンパ節を郭清する。頸動脉鞘を縱に開き, 内頸静 脉を露出し，頸静脉鉗子とテープを用いて，上は箦二 腹筋の後方まで，下は銷骨下静脉がみえる所まで遊離 する。迷走神経の外縁て頸動脉鞘の後板を縱に切り開 き, 内頸静脉周团のリンパ節を含む脂肪組織を後方の 深頸筋膜から外側に向って剥す。頭側ではこの脂肪塊 を乳様突起から切り離し, 下方兄剝す。副神経が現わ れるから損傷しない様に残す。大耳介神経がみえたら やめる。下の方で左側の静脉角のあたりの組織は胸管 損傷を避けるために,すべて結禁する。術前にバター と牛乳と鷂卵から成る曲田食を投与しておき，胸管を 損傷すれば, 乳摩が漏れてわかる様にしている（図 $3)$ 。

次に胸鎖乳突筋の後縁を遊離し,この筋の後方をく ぐらせて, 上下内深頸りンパ節を含を脂肪組織を外側 えひっぱり出し，更に外深頸リンパ節を含む脂肪組織 を後方の斜角筋群から外側方向って剥し, 僧帽筋前縁 まで到る。途中副神経と鎖骨上神経を温存する。下方

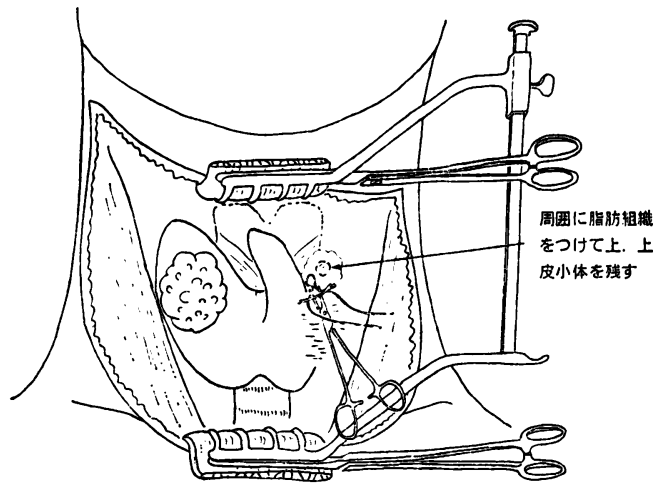

図 1

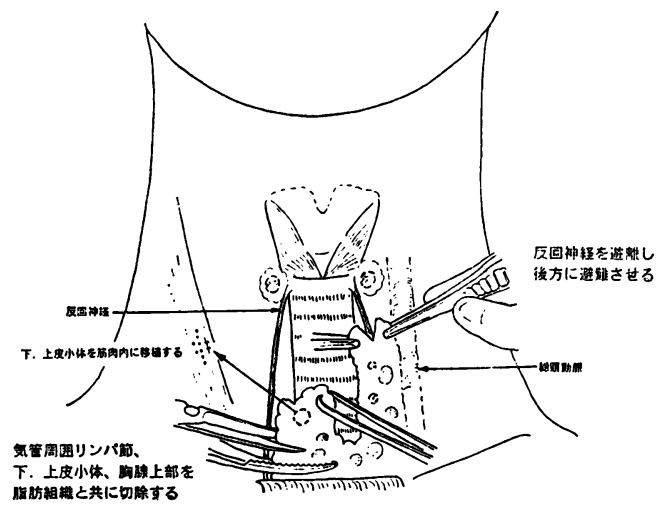

図 2
は鎖骨上神経の近くまで脂肪組織を含めて切除する。 困では説明の都合上, 両側とも外深頸リンパ節まで郭 清する様にかいてあるが，対側は下深頸りンパ節郭清 までに止めることが多い(図 4)。

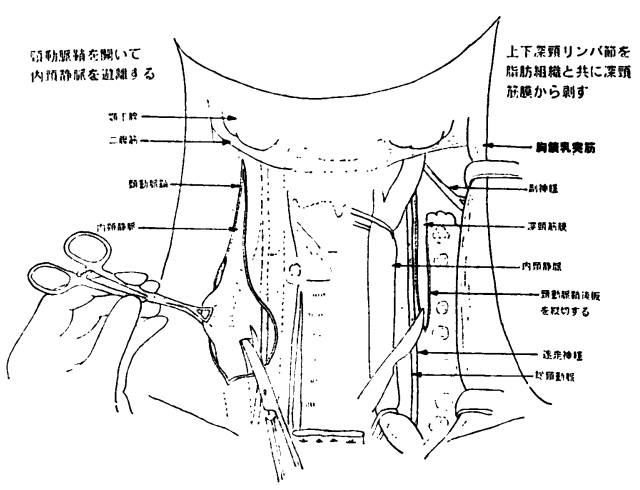

図 3

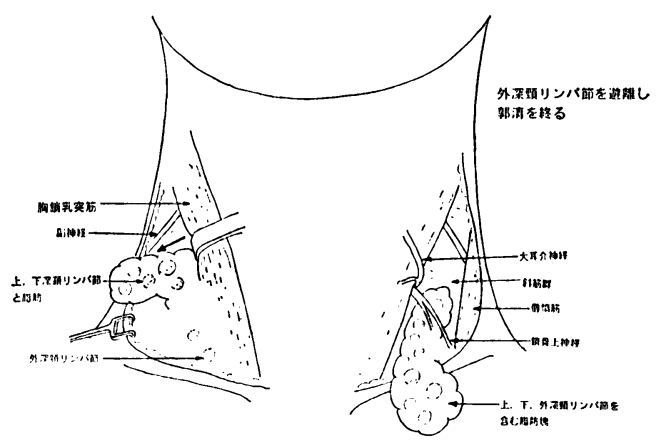

図 4

表 1 リンパ節転移の部位別龄度

76例（ $\mathbf{R}_{1}$ 73例, $\mathbf{R}_{2}$ 3例）

\begin{tabular}{|c|c|c|}
\hline 所属リンパ節 & \multicolumn{2}{|c|}{ 転移例数と転移率 } \\
\hline I 喉頭前 & 2 & $2.6 \%$ \\
\hline II 気管前 & 10 & $13.1 \%$ \\
\hline Uil 気管旁 & 29 & $38.1 \%$ \\
\hline " (対側) & 15 & $19.7 \%$ \\
\hline IV 甲状腺旁 & 8 & $10.5 \%$ \\
\hline $\mathrm{V}$ 上内深頸 & 31 & $40.8 \%$ \\
\hline VI 下内深頸 & 33 & $43.4 \%$ \\
\hline "（対側） & 9 & $11.8 \%$ \\
\hline VII 外深顕 & 9 & $11.8 \%$ \\
\hline VIII 額 下 & 1 & $1.3 \%$ \\
\hline IX 頣 & 0 & $0 \%$ \\
\hline
\end{tabular}




\section{成 績}

この様な系統的リンパ節郭清をやった最近 5 年間で 76例のリンパ節転移の部位別頻度を表 1 に示す（表 1)。問題の気管周囲 リンパ 節群の転移率の高いのが 注目される。合併症としては, リンパ節再発として顎 下, 㲊下を郭清しなかった $\mathrm{R}_{1}$ 症例中, 顎下部から再 発したものが 2 例あったので，広範なリンパ節転移の ある症例は少なくとも䫕下部までは郭清すべきであろ うと思われた。その他の合併症としては76例中50例の
多くに甲状腺全摘を行なったにもかかわらず，永久テ タニーは 1 例しか起きていない。癌に浸潤された反回 神経を 5 本切断したが, 誤って切断したのは 1 例だけ である。乳糜腫が 1 例ある。

死亡例はないが，まだ術後最も古い症例でも 5 年し か経っていないので,この郭清法が古くに行なってい た局所郭清, あるいは無郭清より長期的予後において 優れているかどうか，未だ比較はできない。しかし徹 底した甲状腺切除とリンパ節郭清を行なった割に合併 症は少なく抑えることができた。 
$\mathrm{S}-\mathrm{I}-21$

\section{諸臓器澏におけるリンパ節郭清法一 C 群}

\section{頭頸部癌における頸部りンメ節郭清法}

\section{滰研究会附㕍病院 頭頸料}

内田正興

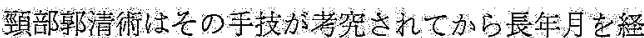

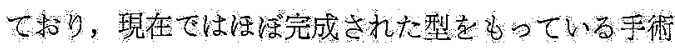

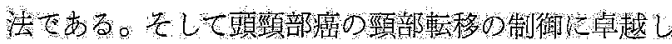

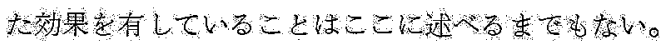

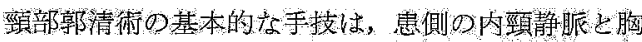

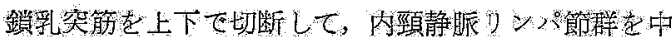

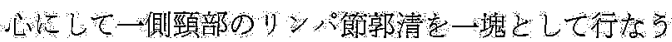

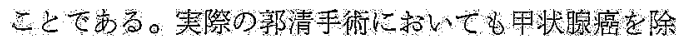

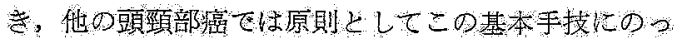
とって乎術各行なるれる。

ただし原発策の部位によっては郭清を部分的に省略

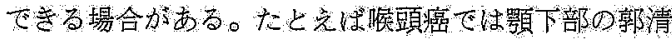
虹必要をはない。下㸶頭頸部食道癌ても同様をる。

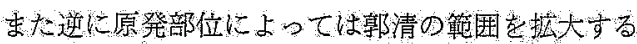
必要がある。たとえば唤頭癌，下咽頭頸部食道癌では

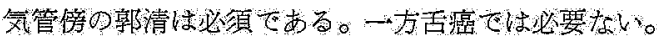

この上るな原発部位と頸転移との相関をみるた炀に 最近の頸部部清例 354 例についてをのルンメ節転移の 分布状況恶好た。

它絬果性

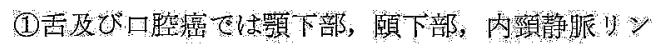

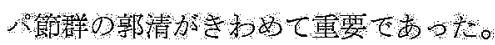

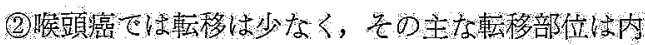

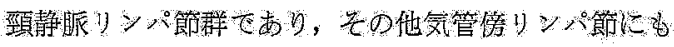

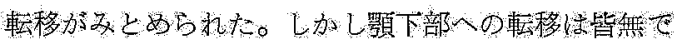
的的。

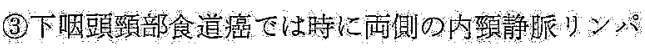

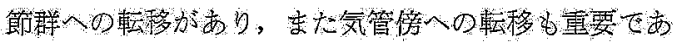

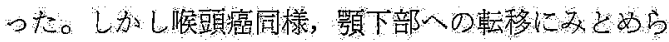
机な的的。

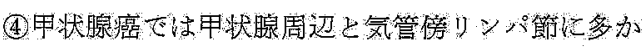
oto

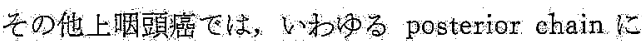
特飞斯移分多加った。

この粶に原発部位の性格により転移の生す当部佳に

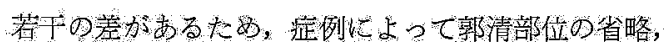
あるい搪大が必要と思われた。

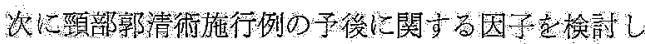

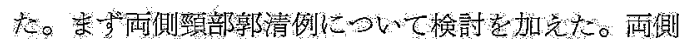
䣆部部清を必要とする例は頻度的には少なく今回历梌

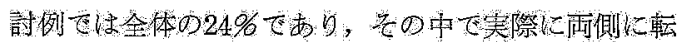

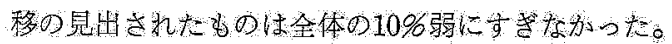
このう名両側同時比頸部部清を行ない，同時闭側転移 の巻とめられた症例性全体の 5 \%弱であった。たたし 両側転移 $\mathrm{N}_{2}$ 例の予後はきわめて悪く長期生存者はい な以力办現状下招的大。

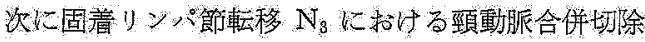
例の寺後尊检詰した。

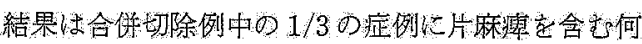

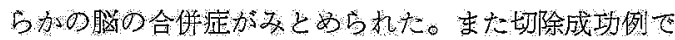

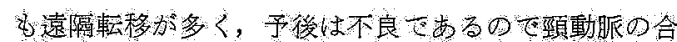

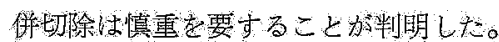

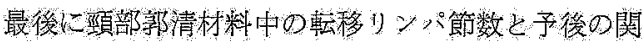

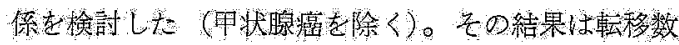

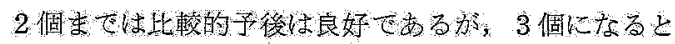

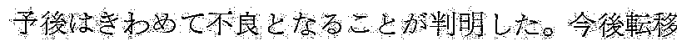
数 3 個以上の症例比 adjuwant chemotherary 的密 要办も知れない。

क飞ष

(1)原登栄的部位に上白頙部転移の分布は異なる。

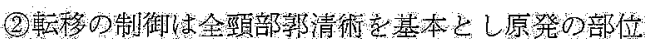

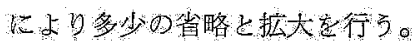

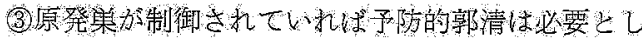
+\$?

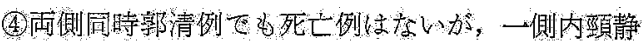
脈の保存が望ましい。

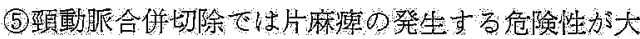
如。

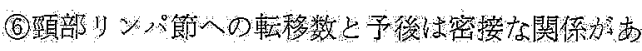
D，3個以上て链予摞不良でった。 


\section{墸贜器癌におけるリンパ節郭清法一 C 群}

$S-I-22$

頭頸部領域癌のりンパ節郭清法についての検討

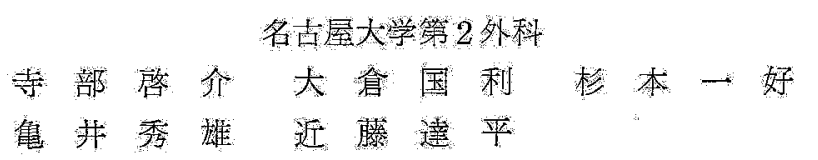

はしめに

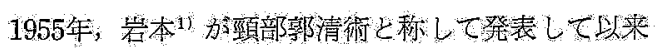
我国でも広く施行されている。頚部郭清術は諸蔵器癌

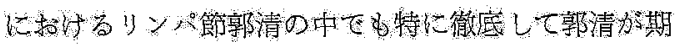

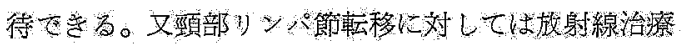

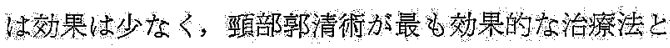

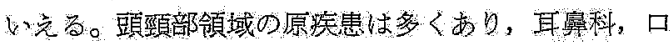
腔外料，外科の領域にわたり颛部郭清術为種及の工夫 少なされてきた。我々は外科医の立場より，下咽頭頚 部食道癌, 舌根部癌, 耳一下腺癌について, 自驗例より 莖部郭清術式についての方針，問題点について檢討し

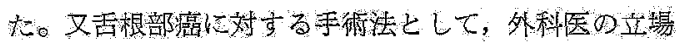

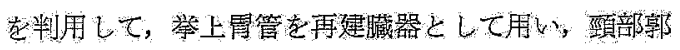
清と原登樂を en bloc に切除可能な術式孝考案した

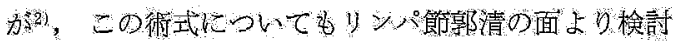
支㧈充。

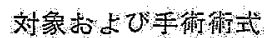

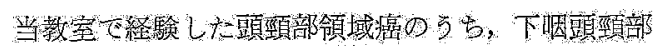
食道癌11例, 舌根部癌 3 例, 耳下腺癌 2 例を対象とし

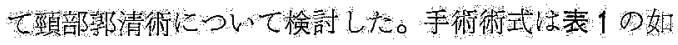

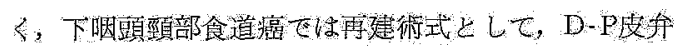

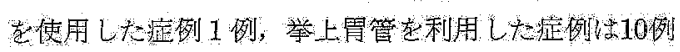

佘 1 手術術式

\begin{tabular}{|c|c|c|}
\hline 疾 墨 名 & 再建兴 & 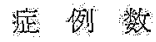 \\
\hline 下咽頭頸部 & D.P 被 角 & 1 \\
\hline 食 道 灙 & 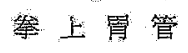 & 10 \\
\hline 号 根 部䄆 & 䅈上胃管 & 3 \\
\hline 耳夲腺癌 & 全 摘 & 2 \\
\hline
\end{tabular}

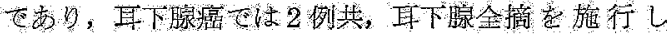

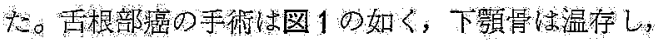

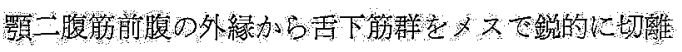
しつつスり，直視下儿安全断端老磼め，又は術中の迅

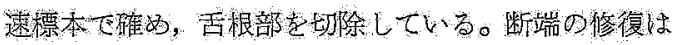

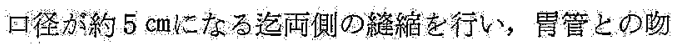
合に倩党る。腹部操作にて霄管老作製し，右罢大檒動

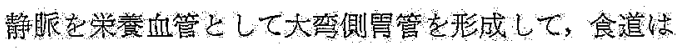
非開胸で拔去し後縰隔経路て作製した冒管を举上し舌 断端および中咽頭後壁を層に縫合して吻合する術式で

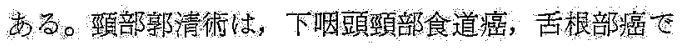

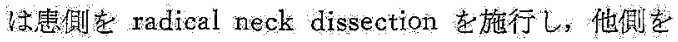
modified neck dissection を施行している。 modified neek dissection では原則として, 胸錤乳突筋, 内 頸静脈, 副神経恃保存している。耳下媳癌は患側の
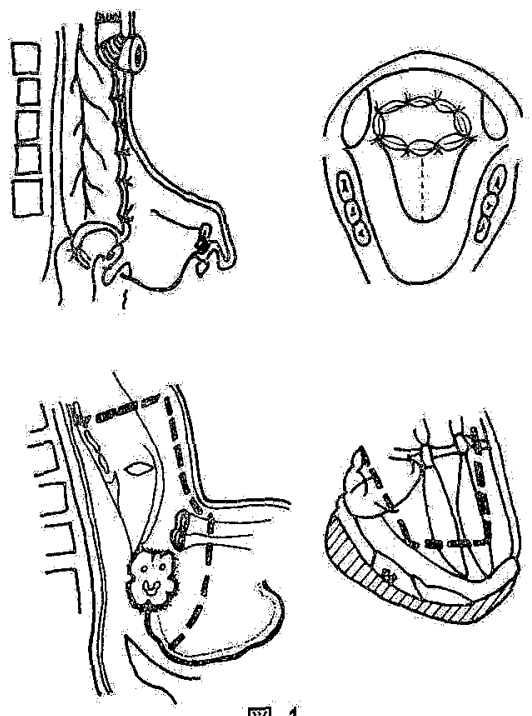

図 1 
radical neck dissection のみとした。皮切はU字状 切開を原則としている。

\section{成 続}

\section{1 ) 両側頸部郭清術の意義}

下咽頭頸部食道癌, 舌根部癌症例には 1 期的に両側 頸部郭清術を施行しているが，その根拠について検討 した。表 2 の如く下咽頭頸部食道癌症例において両側 リンパ節転移症例は11例中 3 例に認められた。舌根部 癌では両側頸部リンパ節転移症例は認められなかっ た。

2) リンパ節転移について

表 2 两側頚部郭清術の意義

（下咽頭頸部食道癌・舌根部癌）

\begin{tabular}{|c|c|c|c|}
\hline \multirow{2}{*}{ 症 } & \multirow{2}{*}{ 例 } & \multicolumn{2}{|c|}{ リンパ節転移 } \\
\hline & & 患 側 & 他 側 \\
\hline \multirow{11}{*}{ 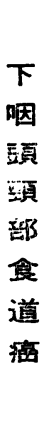 } & 1 & $(+)$ & $(+)$ \\
\hline & 2 & $(-)$ & $(-)$ \\
\hline & 3 & $(+)$ & $(-)$ \\
\hline & 4 & $(+)$ & $(-)$ \\
\hline & 5 & $(+)$ & $(+)$ \\
\hline & 6 & $(-)$ & $(-)$ \\
\hline & 7 & $(+)$ & $(-)$ \\
\hline & 8 & $(+)$ & $(+)$ \\
\hline & 9 & $(-)$ & $(-)$ \\
\hline & 10 & $(+)$ & $(-)$ \\
\hline & 11 & $(+)$ & $(-)$ \\
\hline 舌 & 12 & $(+)$ & $(-)$ \\
\hline $\begin{array}{l}\text { 粮 } \\
\text { 部 }\end{array}$ & 13 & $(+)$ & $(-)$ \\
\hline 焉 & 14 & $(-)$ & $(-)$ \\
\hline
\end{tabular}

下咽頭頸部食道癌のリンパ節転移についてみると表 3 の如く, 最も転移頻度の高い部位は深頸部リンパ節 で11例中 6 例に認め, 上深頸部リンパ節にも 3 例認め た。颠部, 後頸三角リンパ 節には転移を認めなかっ た。舌根部癌ては表 4 の如く 3 例中 2 例に転移が認め られた。症例13は願部リンパ節にも転移を認めた。

\section{3 ) 缅部郭清術後のリンパ節再発よりみた頸部郭清} 術の問題点

頸部郭清術後, 経過観察中にリンパ節再発をきたし た 2 例について検討した。症例 4 は右深頸部リンパ節 と気管周团リンパ節に転移を認めたが, 術後上縱隔に 再発をきたした。症例10は右深頸部リンパ節に転移を 認めたが, 術後 follow up 中に左上深頸部りンパ節 に再発した。

\section{4 ）頸部郭清涌後の合併症}

頸部部清術後の合併症を検討すると16例中14例は合 併症を認めず，2例に内頸動脈よりの出血を認めた。

\section{考 察}

頸部郭清術も種々の検討がなされ，現在確立されつ つある。今光回当教室で経験した頭頸部領域密のうち, 下咽頭頸部食道癌, 舌根部癌耳下腺癌症例について頸 部郭清術を検討した。当数室での頸部郭清術の方針と して, 下咽頭頸部食道癌, 舌根部癌では 1 期的に両側 頸部郭清術を施行している。患側は radical neck dissection を施行し他側は modified neck dissection を施行している。自験例て下咽頭頸部食道癌において 両側に転移を認めているし舌根部癌では舌根部のリン 弪流は両側に流孔ているのて両側に転移する可能性が

表 3 下咽頭頸部食道癌のリンパ節転移

\begin{tabular}{|c|c|c|c|c|c|c|c|c|c|c|}
\hline \multirow[b]{2}{*}{ 症例 } & \multirow[b]{2}{*}{ (1) } & \multicolumn{3}{|c|}{ 患 側 } & \multirow[b]{2}{*}{ (5) } & \multirow[b]{2}{*}{ (1) } & \multicolumn{3}{|c|}{ 他 側 } & \multirow[b]{2}{*}{ (5) } \\
\hline & & (2) & $\begin{array}{l}\text { (3) } \\
\text { 中下 }\end{array}$ & (4) & & & (2) & $\begin{array}{l}\text { (3) } \\
\text { 中下 }\end{array}$ & (4) & \\
\hline 1 & $(-)$ & $(-)$ & $(+)(+)(-)$ & $(-)$ & $(t)$ & $(-)$ & $(-)$ & $(-)(+)(-)$ & $(-)$ & $(+)$ \\
\hline 2 & $(-)$ & $(-)$ & $(-1)(-)(-)$ & $(-)$ & $(-)$ & $(-)$ & $(-)$ & $(-)(-)(-)$ & $(-)$ & $(-)$ \\
\hline 3 & $(-)$ & $(-)$ & $(-)(-)(-)$ & $(-)$ & $(t)$ & $(-)$ & $(-)$ & $(-)(-)(-)$ & $(-)$ & $(-)$ \\
\hline 4 & $(-)$ & $(-)$ & $(-1+1)(-)$ & $(-)$ & $(t)$ & $(-)$ & $(-)$ & $(-)(-)(-)$ & $(-)$ & $(-)$ \\
\hline 5 & $(-)$ & $(-)$ & $(+)(+)(+)$ & $(-)$ & $(-)$ & $(-)$ & $(-)$ & $(-)(+)(-)$ & $(-)$ & $(-)$ \\
\hline 6 & $(-)$ & $(-)$ & $(-1)(-1)$ & $(-)$ & $(-)$ & $(-)$ & $(-)$ & $(-)(-)(-)$ & $(-)$ & $(-)$ \\
\hline 7 & $(-1$ & $(t)$ & $(-)(-)(-)$ & $(-)$ & $(-)$ & $(-)$ & $(-)$ & $(-)(-)(-)$ & $(-)$ & $(-)$ \\
\hline 8 & $(-)$ & $(-)$ & $(t)(t)(t)$ & $(-)$ & $(-)$ & $(-)$ & $(-)$ & $(t)(+)(t)$ & $(-)$ & $(-)$ \\
\hline 9 & $(-)$ & $(-)$ & $(-)(-)(-)$ & $(-)$ & $(-)$ & $(-)$ & $(-)$ & $(-)(-)(-)$ & $(-)$ & $(-)$ \\
\hline 10 & $(-)$ & $(-)$ & $(-)(+)$ & $(-)$ & $(-)$ & $(-)$ & $(-)$ & $(-)(-)(-)$ & $(-)$ & $(-)$ \\
\hline 11 & $(-)$ & $(-)$ & $(-i+1+)$ & $(-)$ & $(t)$ & $(-)$ & $(-)$ & $(-)(-)(-)$ & $(-)$ & $(-)$ \\
\hline
\end{tabular}
(1) 願部
2) 顥下三角
(3) 深新部

(4) 後頚三角

(5) 気管周囲 
第 9 回学術集会シンポジウム

表 4 舌根部癌耳下腺癌のリンパ節転移

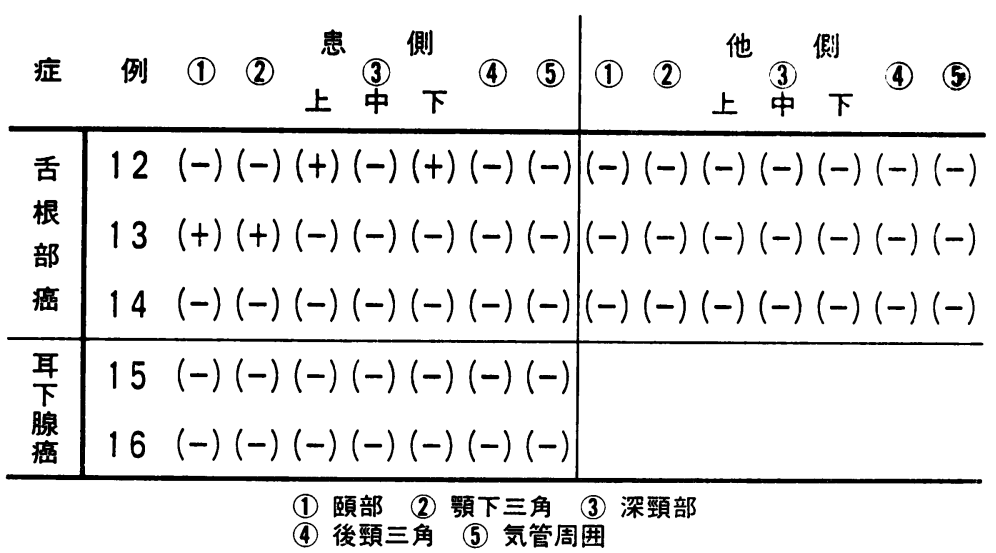

高い ${ }^{2)}$ : 1 期的に行う理由としては現在の麻醉法の進 歩等により, 両側頸部郭清術を施行しても, そたほど の手術侵襲にはならない。当数室では 1 側の頸部郭清 中に腹部操作と 2 チームに分かれて手術を施行してい るので時間的にもそれほど長くかからないからであ る。他側は modified meck dissection を施行するの は, 頸部の変形, 局の落下, 肩運動能の低下の予防と 内頸静脈両側結禁による頭蓋内左穴進を防ぐためであ る4)。頸部郭清術は主としてメスを多用している。メ スを多用する術者と，八サミを使用する術者とに分か れるが，メスの方が正確な切離が可能と思われメスを 多用している。病巣適出にあたっては頸部郭清術より 始め en bloc に原発巣を摘出している。これはリン パ節郭清法の基本であり非常に重要であると思われ る。頸部郭清範囲は後縁は僧帽筋前縁, 上限は顎二腹 筋後腹の高さ，下限は鎖骨上としている。特に注意を しているのは上限で深頸リンパ節転移を少なからず 認めるのが上深頸部りンパ節郭清はていねいに施行し ている。頸部リンパ節再発よりみて反省点をひろって みると下咽頭頸部食道癌症例て術後上絽隔リンパ節に 再発をきたした。この症例は腫瘍の下縁が頸部食道の 下方迄浸潤していた。頸部食道癌症例では上縱隔りン ハ節転移をきたす可能性があり，頸部食道癌で下方迄 浸潤している症例には上縦隔郭清の必要性を示唆して おり今後症例か重ねて検討したい。他の 1 例は術後他 側の上深頸部リンパ節に再発をきたした。この症例は modifid neck dissection を施行した側に再発した が，上深頸部リンパ節郭清が不充分であったのか, 内 頸静眽保存のためか，検討すべき点である4)。我々は 舌根部癌に対する手術法として挙上胃管を用いる方法 を考案したが，この方法は舌根部の展開が容易で病巣
を術野に簡単に引きだすことができ，直視下に安全断 端を確認して切除することができる又挙上筩管を用 いる為の腹部操作は簡単で外科的侵襲は少い。両側頸 部部清術後, 原発巣を含め en bloc な切除ができ根 治性を高め, 治療成績の向上が期待できる思わた る。又術後早期より経口摂取ができ街後の adjuvant therapy も可能となる。

頸部郭清術後の合併症をみると16例中 2 例に合併症 をみた。2 例共内頸動脈よりの出血であった。この 2 例は感染が主原因と思われドレナージが不充分であっ たことが予想された。他の14例は何の合併症もなく経 過した。以上頸部郭清術について当数室の経験を述へ たが今後症例を重ねて検討したい。

$$
\text { まとめ }
$$

当教室で経験した下咽頭頸部食道癌, 舌根部癌, 耳 下腺癌について頸部郭清術および舌根部癌に対する手 術について検討したが, 術式, 再発, 合併症について ほぼ満足すべき結果が得られたが，まだ多くの検討す ベき点が残されており，今後症例を重就て，少くとも 頸部郭清術後の頸部リンパ節再発は無にすべく努力し ていきたい。

\section{文 献}

1) 岩本彦之烝: Radical neck discection に就て 耳㔣と臨床 I : 44 46, 1955.

2 ) 龟井秀雄, 杉本一好, 寺部啓介他: 進行舌根部癌 に対する術式について 一新しい到達経路と胃管 再建法一 日消外会誌 $16: 141 \sim 145,1983$.

3 ）松浦3秀博, 河辺義孝: 頸部郭清術変法の分類につ いての検討 癌の臨, $22: 438 \sim 444,1976$.

4) 村上泰：頸部郭清術。外科 Mook, Na 7 pp.94 108 金原出版, 1979. 


\title{
$\mathrm{S}-\mathrm{I}-23$
}

\section{諸臓器癌におけるリンパ節郭清法一C群}

\section{乳癌根治術に怙け名りン゙゚゚節郭清法}

\author{
近畿大学第 1 外科 \\ 岩侤善二佐伯锚司大和宗久 \\ 舆野清隆安富正幸陣丙傳之助
}

\section{稭 言}

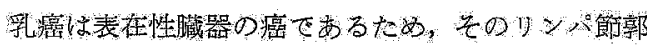

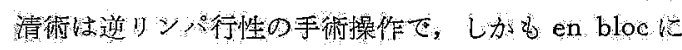

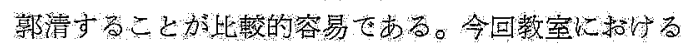

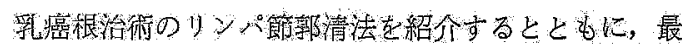
近街前の乳房の y $ン$ 勘態の成績について子報告す zo.

\section{対象斿法}

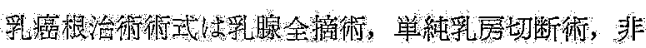

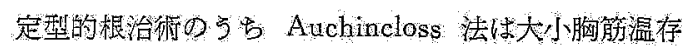

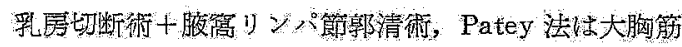

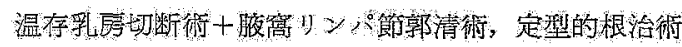

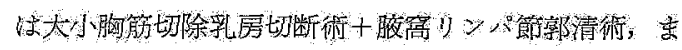

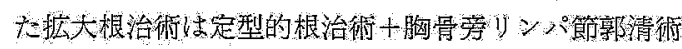

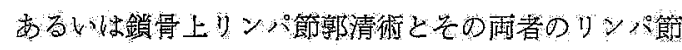
渟清術てある。教室において 9 年間の根治術を施行し

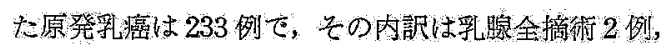

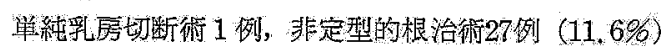

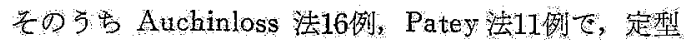

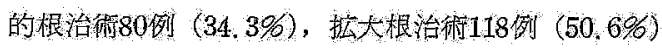

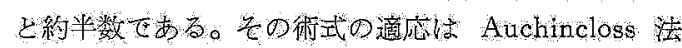

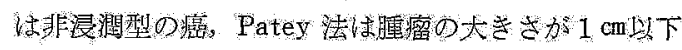

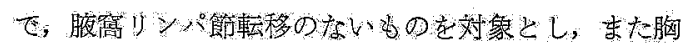

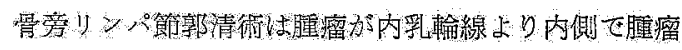

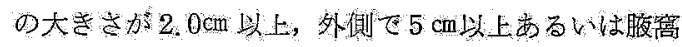

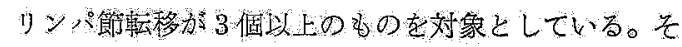

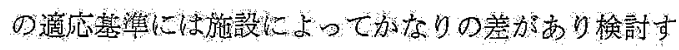
Ne点加多。

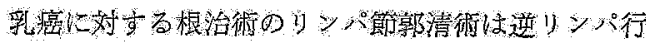

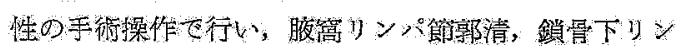

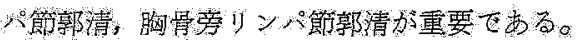

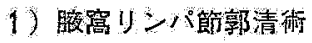

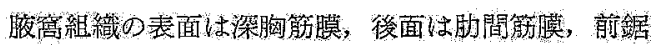

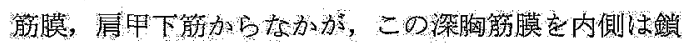

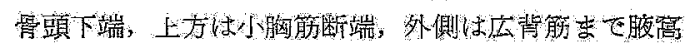

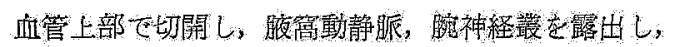

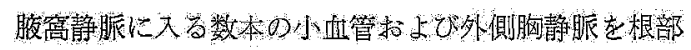

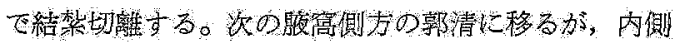

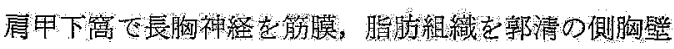

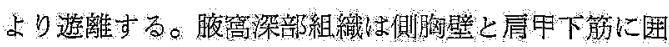

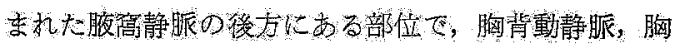

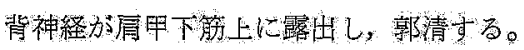

2) 鑜尐下リンパ節敦清術

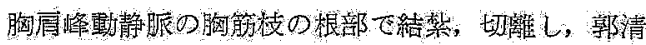

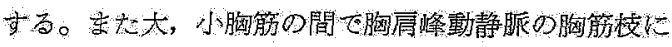

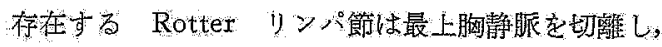

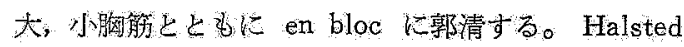

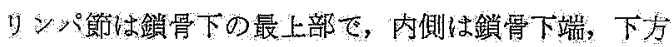

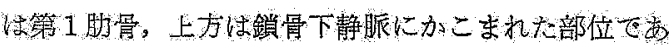
\%

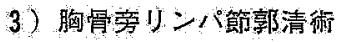

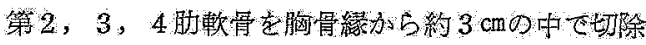

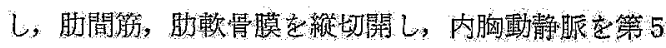

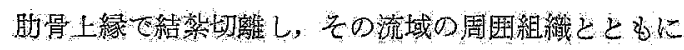

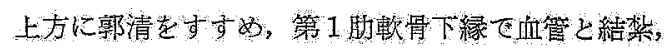

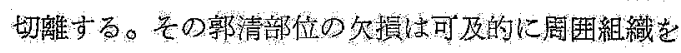

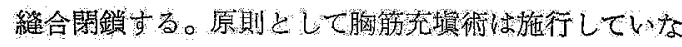
W\%.

4) $\sin$ Te HSA によるリンハ動態からみたりンハ 節郭清術

99m Te HSA (Human Serum Albumin) b站照耕

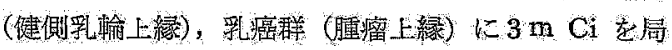


第 9 回学術集会シンポジウム

\begin{tabular}{|c|c|c|c|}
\hline 型式 & 対照群 & 乳癌群 & 部位別 \\
\hline \multirow[t]{2}{*}{ 腋盆 型 } & \multirow{2}{*}{$\begin{array}{c}0 / 8 \\
(0.0 \%)\end{array}$} & \multirow{2}{*}{$\begin{array}{c}2 / 16 \\
(12.5 \%)\end{array}$} & $\begin{array}{l}\text { 内側腫瘤 } \\
1 / 12(8.3 \%)\end{array}$ \\
\hline & & & $\begin{array}{l}\text { 外側腫瘦 } \\
1 / 4(25.0 \%)\end{array}$ \\
\hline \multirow[t]{2}{*}{ 鎖骨下型 } & \multirow{2}{*}{$\begin{array}{c}0 / 8 \\
(0.0 \%)\end{array}$} & \multirow{2}{*}{$\begin{array}{c}0 / 16 \\
(0.0 \%)\end{array}$} & $\begin{array}{l}\text { 内側腫瘤 } \\
0 / 12(0.0 \%)\end{array}$ \\
\hline & & & $\begin{array}{l}\text { 外側腫瘤 } \\
0 / 4(0.0 \%)\end{array}$ \\
\hline \multirow[t]{2}{*}{ 胸骨旁型 } & \multirow{2}{*}{$\begin{array}{c}8 / 8 \\
(100.0 \%)\end{array}$} & \multirow{2}{*}{$\begin{array}{r}14 / 16 \\
(87.5 \%)\end{array}$} & $\begin{array}{c}\text { 内側腫瘤 } \\
11 / 12(91.7 \%)\end{array}$ \\
\hline & & & $\begin{array}{l}\text { 外側腫瘤 } \\
3 / 4(75.0 \%)\end{array}$ \\
\hline
\end{tabular}

図 1 放射図の型式

注し, gamma scintigram を測定した。その scintigram のリンパ動態のパターンを胸骨旁型, 腋窩型, 鎖骨下型の 3 型に分類すると, 対照群は 8 例全例胸骨 旁型を示すが, 乳癌群は胸骨旁型16例中14例(87.5\%) で,そのうち内側腫瘤 $91.7 \%$, 外側腫瘤 $75.0 \%$, 腋窩 型は16例中 2 例 $(12.5 \%)$ である。しかし鎖骨下型は 認めなかった（図 1)。

次にリンパ流の速度をクリアランス（T 1/2）でみ ると, 対照群では $80.4 \%$, 乳癌群 $41.7 \%$ と担癌乳房が

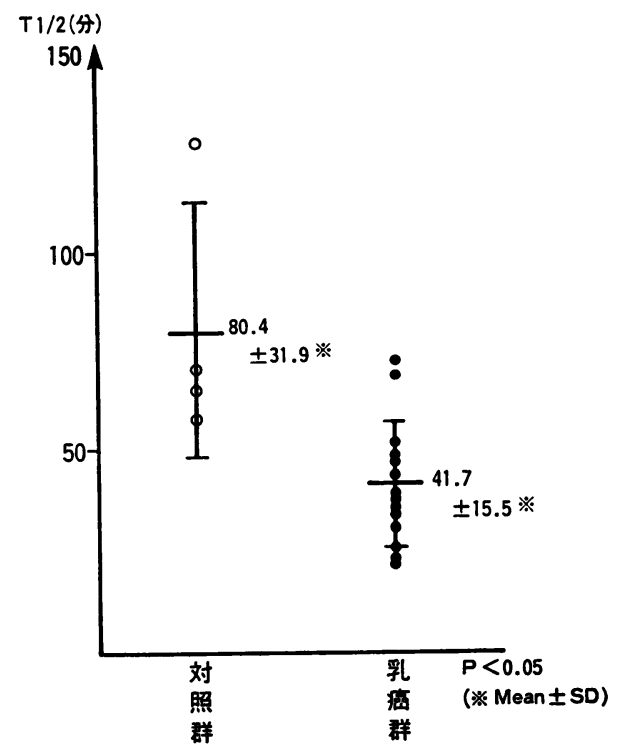

図 2 クリアランス (T1/2)

正常乳房に比し約 2 倍の速度であることがわかった (図 2 )。

$$
\text { ま亡め }
$$

まだ結論は出ていないが，術前のリンパ動態からみ たリンパ節郭清法も考慮すべきであると考える。 


\title{
諸臓器癌にむけるリンパ節郭清法一C群
}

\section{$\mathrm{S}-\mathrm{I}-24$}

\author{
皮屬悪性腫瘍とリンパ節郭清 \\ 传冬総合满院 形成外科 \\ 安滕 正 英
}

はしめめ

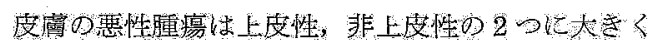
分類されるが，非上皮性の悪性腫瘍は比較的少ないた

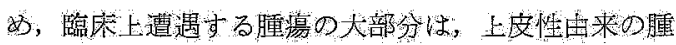

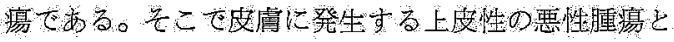

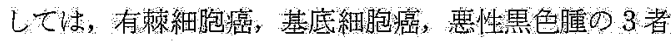
が代责的となる（表 1)。これらのなかで悪性黒色腫

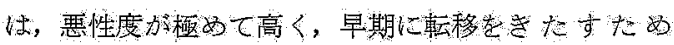

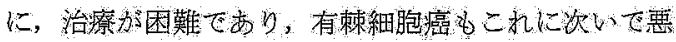
性である。しかし基底細胞癌は，謴瘍を形成して，組

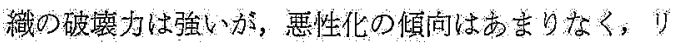

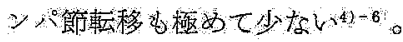

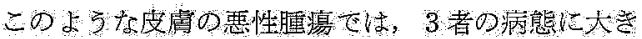

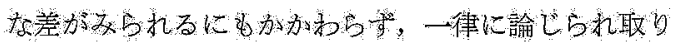

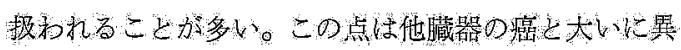

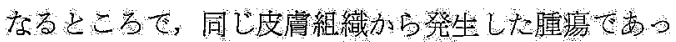

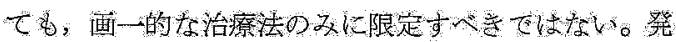

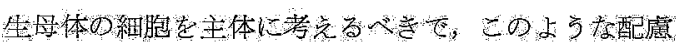

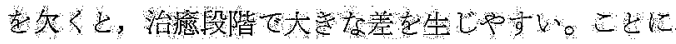
矿属り

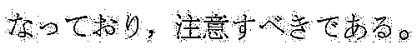

\section{方法}

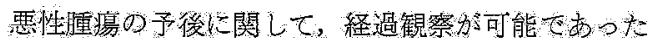

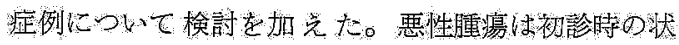

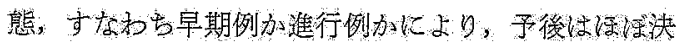

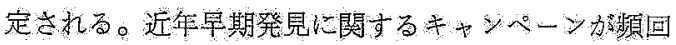
に行初れており，初期に来院する症例为普加している

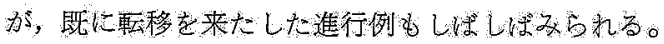

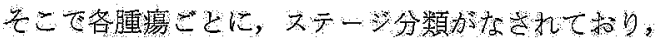

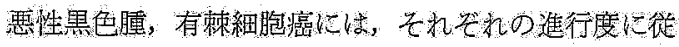

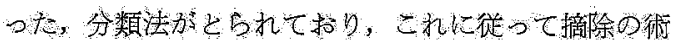

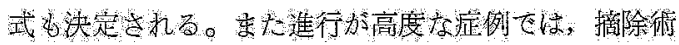

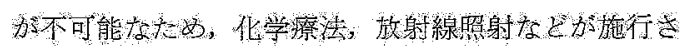
机てい。

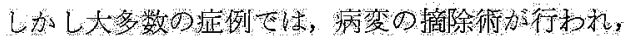

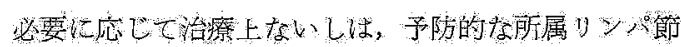

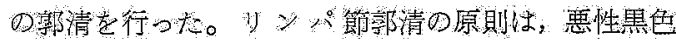
腫, 有辣細胞癌て積極的な予防的郭清を゙, 基底細胞癌 では，必要と認められた症例のみとし，他の悪性堙瘍 で症例により決定した（表 1)。但し治療が臨床の 複数の科にわたっで行われたた狗，リンハ節郭清には

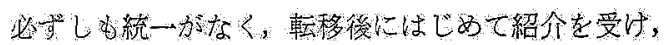
郭清に至った症例名含まれている。また基底細胞癌に

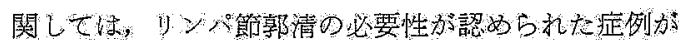

\section{表 1 ，皮膚悪性腫瘍}

1: 上度性䭪瘍

(1) 皮膚祒

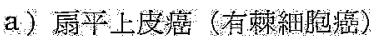
枟移傎向少なく，局所リンパ節まで。 顔面・钼部他好発。 予防的郭清情局所りンバ節案で。

b) 基底細胞癌 転移形成好炼をえどなし。 顔面裂に一致して発生。 速要時の就清。

厄) 付属器ゆ䄆 汗腺澞, 皮脂腺澏なと。

（2）悪性黒色㯵 転移傾向分強心。 病巣の広籍切除とリンパ節の治療ならびに 予捄的郭清。

2, 非上度性腫瘍 線維肉堙, 脂肪肉腫灷と。 
なく，全例に郭清が施行されていない。

\section{症 例}

\section{患者 68嵅, 女性。 \\ 主訴右腋㸗腫瘍}

既往歴 特記すべきことなし

現病歴 2 年前に右拇指爪下に，黑色の色素沈着か 出現し放置していたところ，除々に大きくなったため 皮膚科を受診，悪性黑色腫の彰断を受け，整形外科に て右拇指の基節部切断, 示指の移植による拇指化手術 を受けた。

その後は 3 力月に 1 回外来を受診し, 術後の経過観 察を受けていたが, 悪性腫瘍に対する化学療法は施行 されなかった。最近右腋䈑に $2 \times 3 \mathrm{~cm}$ 大の腫瘍を触れ ることに気付き, 悪性黑色腫のリンパ節転移との診断 を受け，腋窩リンパ節の郭清を目的として入院した。

臨床経過手術は腫瘍を含めて, 右腋窩のリンパ 節, 脂肪組織を en bloc に摘除した。さらに大胸筋, 小胸筋下のリンパ節も脂肪組織とともに摘除, 腋窩部 を可能な限り広範囲に郭清した。摘出した腫瘍は, 割 面が黒色で中心部が壊死となり, 悪性黒色腫の転移が 肉眼的にも明らかであった。腋窩の創は, 初期にリン パ腋の漏出を大量に認めたが, 徐々に減少して 3 週間 後に閉鎖した。創の治㾑後に，転移を防止する目的 て，化学療法を点滴投与により開始したが，白血球の 減少と脱毛が著明となり, 静脈内投与を中断して, 経 口剂に変更して投与を続行した。

しかし化学療法続行中にもかかわらず，8力月後に 胸部レ線で肺への転移が認められ，エコー検查では肝 への転移も証明されて, 全身衰弱が急激に進行し死亡 した。肝・肺の転移は多発性て, 腹腔内リンパ節の腫 大も著明であった。拇指切断が行われた局所には, 再 発が認められず，局所リンパ節転移から，肺・肝への 遠隔転移に至ったものと考えられる。この症例では， 初回手術より腋窩転移の出現まてに 2 年 2 力月を要し ており, 原発巣手術時に, 腋窝リンパ節郭清を同時に 施行すべきであったと思われる。これは悪性腫瘍にお ける, 予防的リンパ節郭清の概念が, 臨床各科におい て，不統一であることに原因がある。

\section{患者 74歳, 男性。 \\ 主訴左大腿潰瘍}

既往歴 特記すべきことなし

現病歴 6 力月前に左大腿に小さな硬結が生じた が，疼痛もなく放置していたところ，徐々に大きくな り表面が潰瘍化して来院した。
腫瘍は $3 \times 3 \mathrm{~cm}$ 大て，表面に潰瘍を伴い，内腔には 壊死を伴う膿瘍を形成していた。

臨床経過 潰瘍は肉眼的に悪性が疑われたため, 辺 縁より $3 \mathrm{~cm}$ 以上離して皮膚切開を加え，周囲組織とと もに摘除し, 左鼠径部のリンパ節郭清を同時に行っ た。リンパ節の腫大は軽度であったが，割面の検索で 転移が肉眼的に認められたため, 鼠径部全体の広範囲 な垶清を施行, 皮膚の大きな欠損部は, 大網移植を行

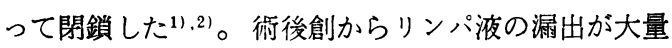
にみられたが, 大網からの收収もあり徐々に減少して 1 力月後に閉鎖した。

組織学的に有棘細胞癌と判明し, 放射線照射を行っ たが，3カ月後に局所再発を来たし，同時に肺の多発 転移により，6力月後に死亡した。皮庩の切除範囲の 不足と, 癌の進展が高度であったと思われる。

患者 63歳, 男性。

主訴右大腿腫瘍

既往歴 特記すべきことなし

現病歴 2 年前に右足背に大豆大の腫瘍が出来た が, 放置していたところ徐々に大きくなり，表面にビ ランを生じたため皮膚科を受診，切除術を受けた。腫 瘍は有棘細胞癌で, 組織学的には grade I と判定さ れたため, 経過観察中に術後 3 カ月で, 右大腿部にリ ンパ節転移を来たし，リンパ節郭清を目的に入院し た。腫瘍は $2 \times 1.5 \mathrm{~cm}$ 大で, 周囲との瘉着はなかった。

臨床経過 鼠径部は腫瘍を含めて, リンパ節, 脂肪 組織とともに en bloc に摘除した。腫瘍は中心部に 壊死を伴う充実性で, リンパ節と思われた。組織学的 には, 足背の腫瘍と同一であり, 有棘細胞癌の転移と 診断された。術後は創閉鎖と同時に，放射線照射を開 始, 化学療法も長期にわたって施行した。転移巣切除 後 3 年の現在, 再発の徵候は認められない。

患者 74葴, 男性。

主訴右大腿部腫湯

既往歴 31 藏時に肺炎，66衤時に虚血性心疾患と診 断され, 現在も治療中。

現病歴 15年程前から右第 2 趾の爪下に, 黒色の母 斑を認めるも放置していたところ, 最近右大腿に腫瘍 を触れ来院した。右第 2 趾の母斑は $0.5 \times 0.5 \mathrm{~cm}$ 大で, 一部分が爪下にみられ, 腫瘍は $2 \times 2 \mathrm{~cm}$ 大と $1 \times 1.5$ 大の 2 つを皮下に触知した。

臨床経過 右第 2 趾は基節より切断, 鼠径部はリン ハ節を含めて, 広範囲に郭清した。腫瘍の内腔は, 黒 色を呈し明らかな転移であり, 第 2 趾の爪下ょり悪性 黒色腫が証明された。術後は化学療法を施行, 現在経 


\section{日本外科系連合学会誌 第12量}

過観察中てあるが， R-Iシンき，CTscanにより後腹

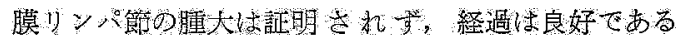
(図 1, 2)

\section{結 果}

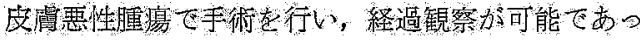

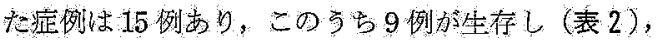

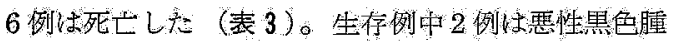

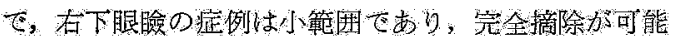
でった。残りの1例は，臨床経過の中巴述凶た加，

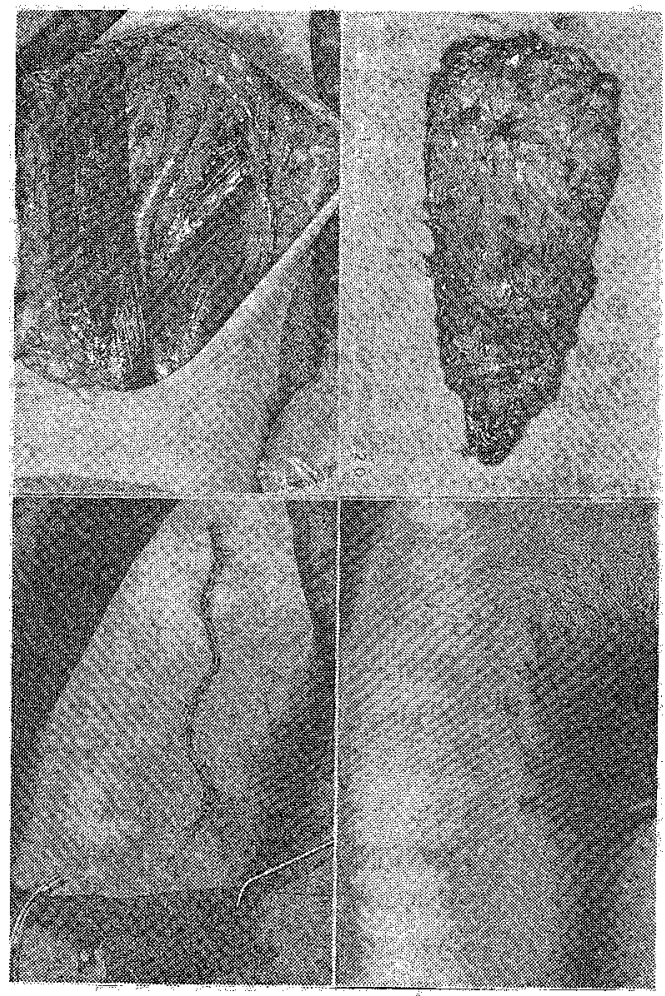

図 1 症例 74歳, 男性

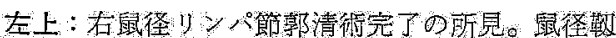

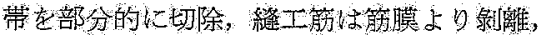

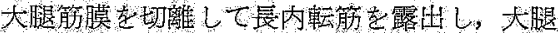

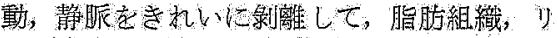

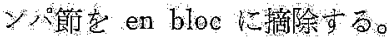

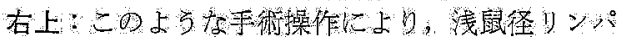

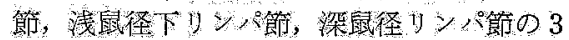
者加，一熄飞し飞摘除己机た。

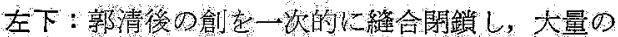

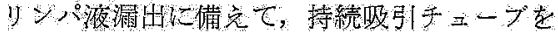
㩑或过。

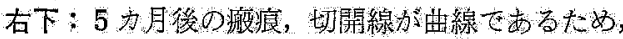

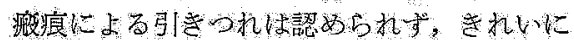
治湑している。

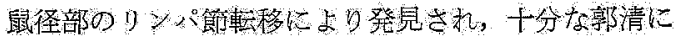

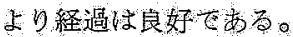

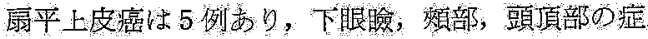

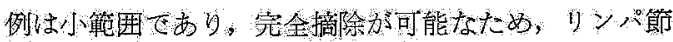

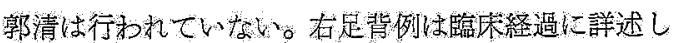

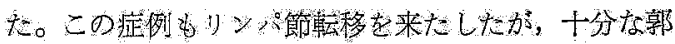

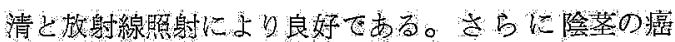

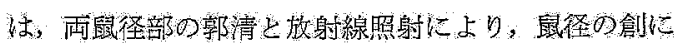

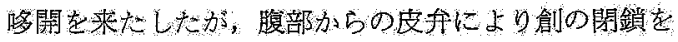

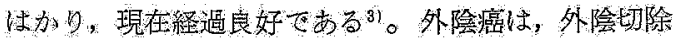

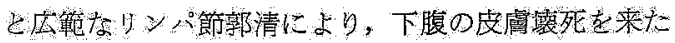

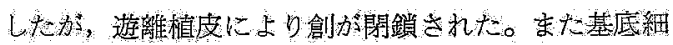

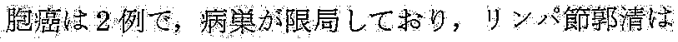
不婪㐫与た。

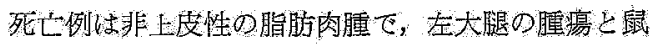

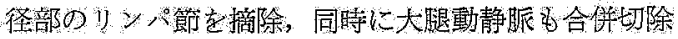

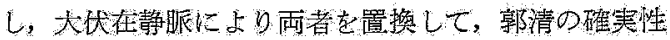

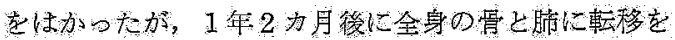
来大して死亡しt。組織学的儿悪性度加高々，根治的

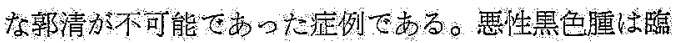

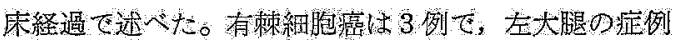

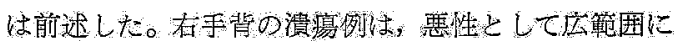

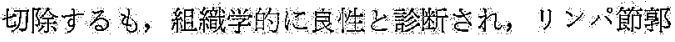

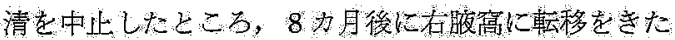

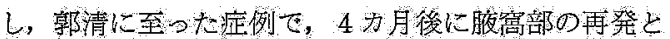
脚軾移により歹しした。

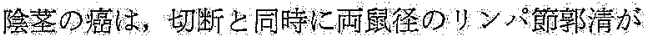
行加たか，原発策加進行癌てあったため，早期右 鼠徍部儿再発し，肺転移により死亡している。また基

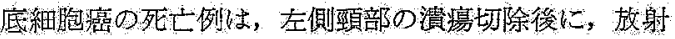

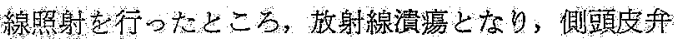

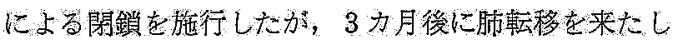
C死亡t。

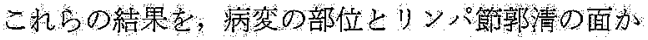

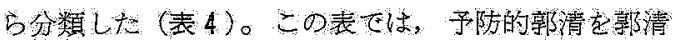

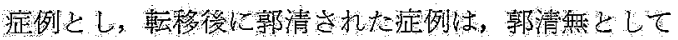

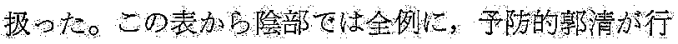

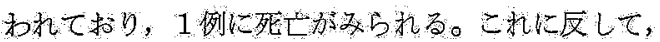

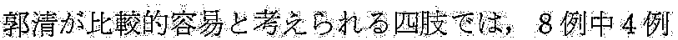

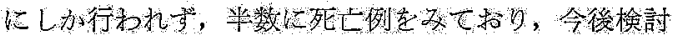

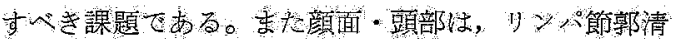

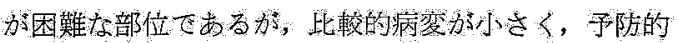

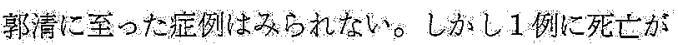

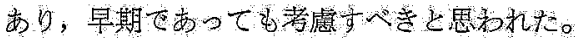

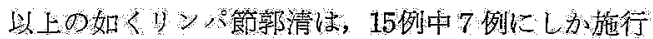




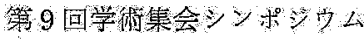

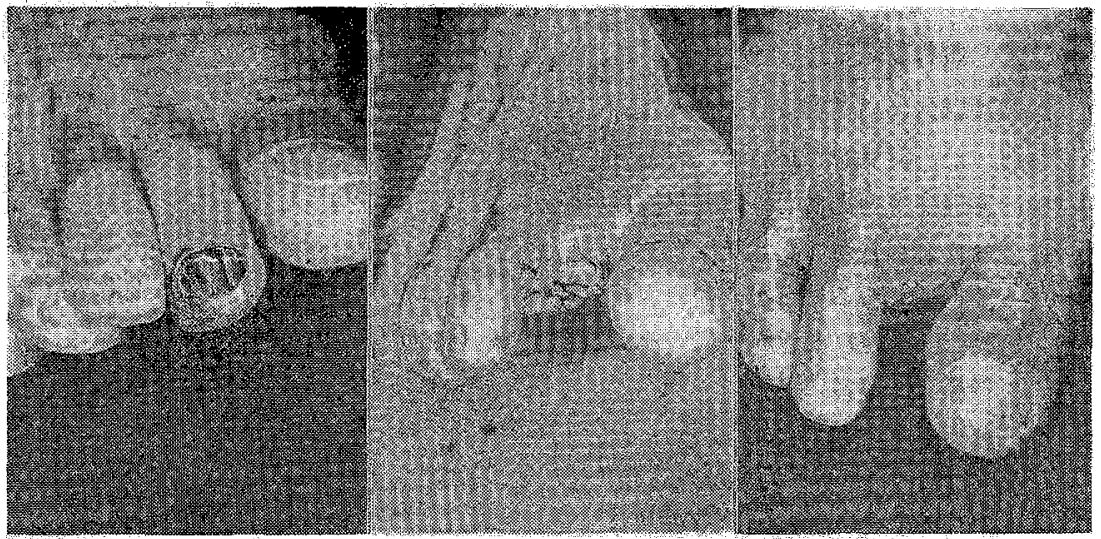

図 2 図 1 巳同一症例

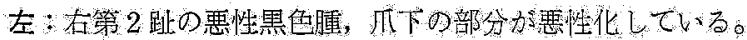

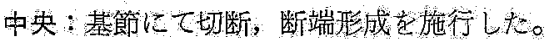

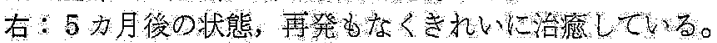

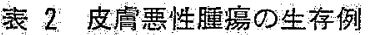

\begin{tabular}{|c|c|c|c|c|c|c|}
\hline $\mathrm{No}$ & 症例 & 診断 & 病变 & yメN即郭清 & 化学潦羕 & 放射線照射 \\
\hline 1 & 63歳，罗性 & 聏平上度意 & 香是背 & 在武偦 & 煘 期 & 右鼠徍 \\
\hline 2 & 业歳，男泩 & 悪禇黑色腫 & 右淛 2 趾 & 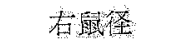 & 晨 期 & $(-)$ \\
\hline 3 & 64瓷，男性 & 悪性黑色䐺 & 右下眼臉 & $(-)$ & $(-)$ & $(-)$ \\
\hline 4 & 61歳，女性 & 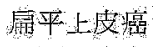 & 右颗部 & $(-)$ & $(-)$ & $(-)$ \\
\hline 5 & 67瓷, 男性 & 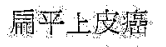 & 頭頂部 & $(-)$ & $(-)$ & $(-)$ \\
\hline 6 & 46瓷, 罗性 & 扉平 $\mathrm{E}$ 度灙 & 陰 淕 & 禹鼠烽 & 短，期 & 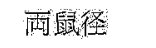 \\
\hline 7 & 42 喊, 女胜 & 府平上度癌 & 知 除 & 峏酮经 & 長 期 & 雨鼠径 \\
\hline 8 & 64歲，男性 & 基底細胞灌 & 左是背 & $(-)$ & $(-1)$ & 左足背 \\
\hline 9 & 65柴，努性 & 基媙細胞癌 & 左下腿 & $(-)$ & $(-)$ & 左下枨 \\
\hline
\end{tabular}

表 3 皮盧慗性腫懪による死亡例

\begin{tabular}{|c|c|c|c|c|c|c|}
\hline $\mathrm{No}$ & 症例 & 診䉼 & 病变 & 1)ンパ節部清 & 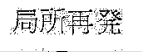 & 転 䅑 \\
\hline 1 & 34歳, 男性 & 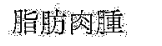 & t土大腿 & 差鼠程 & $(-)$ & 骨 \\
\hline 2 & 68歲，女性 & 悪性黑等腫 & 石挶指 & $(-)$ & $(-)$ & 掖窝・腽 \\
\hline 3 & 74 歲，男栍 & 病平 $\mathrm{E}$ 皮癌 & 左太腿 & 左鼠程 & 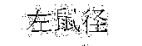 & 肺 \\
\hline 4 & 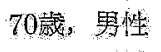 & 届平上度癌 & 右事背 & $(-)$ & $(-)$ & 腋荅・墌 \\
\hline 5 & 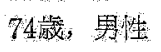 & 基底細胞癌 & 友側䫫 & $(-)$ & $(-)$ & 腈 \\
\hline 6 & 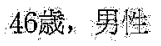 & 渄平上皮澺 & 陰 蒸 & 雨鼠徍 & 有鼠径 & 需 \\
\hline
\end{tabular}

表 4 部位別症例数し予後

\begin{tabular}{|c|c|c|c|}
\hline 病 变 & 生 存 & 死亡 & 計 \\
\hline 四肢 & $4(2)$ & $4(2)$ & $8(4)$ \\
\hline 旗面，頭部 & $3(0)$ & $1(0)$ & $4(0)$ \\
\hline 陰 部 & $2(2)$ & $1(1)$ & $3(3)$ \\
\hline 貄 & $9(4)$ & $6(3)$ & $15(7)$ \\
\hline
\end{tabular}

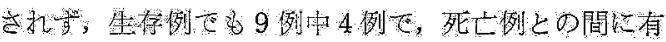

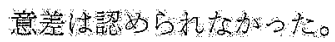

さらに転移後のリンパ節郭清は，上肢の 2 例炕行る

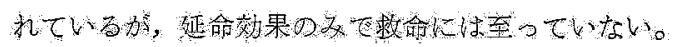

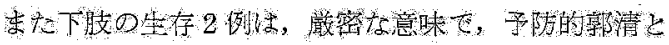

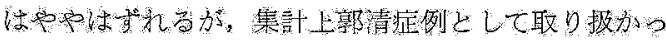
tis 
おわりに

皮膚悪性腫瘍の臨床例を中心にして, リンパ節郭清 と予後について検討した。症例数が15例で，母体とし ては少ないが, 他の悪性疾患と比較して, リンパ節郭 清の比率が極めて低いことが判明した。これは治療が 臨床の各科にわたって行われることも1つの原因であ るが，疾患に対する認識の低さにも起因している。こ れは予後にも大きく作用し，非常に高い死亡率として あらわれている。ことに死亡例を検討すると, 病巣切 除時に, 予防的リンパ節郭清を行えば，救命し得たと 思われる症例がみられる。そこで早期の皮虙悪性腫瘍 は，積極的に予防的リンパ節郭清を行うべきである。 郭清の術式は, 鼠径, 腋窝, 頸部に関しては, 確立さ れており，手技も比較的容易である。それ故これらの リンパ節郭清により, 病変の波及を防賒出来れば, 予 後は飛蹋的に改善される。
文 献

1) Ando, M. and Ando, Y. : Study on Omental Flap and Skin Graft for Radiation Ulcer on Chest Wall, Transactions of the Seventh International Congress of Plastic and Reconstructive Surgery : 205-208, Rio de Janeiro, Brazil, May 20-25, 1979.

2) 安藤正英: 鼠径部病変と修復術, 日形成外会誌, $2: 398,1982$.

3 ) 安藤正英, 安藤幸穂: 局所皮弁の忘用一その 3 腹部, 背部一, 日形成外会誌, $2: 240,1981$.

4) 川村太郎, 池田重雄 : 癌腫とその前駆症, 臨床皮 虐科全書第 5 巻, P 427, 金原出版, 東京, 1971.

5 ) 藤浪得二, 三木吉治, 宮地 徹: 皮膚癌の統計的 観察, 日皮会誌, $72: 557,1962$.

6 ）今共清治：皮痛癌及び悪性黒色腫の統計的観察, 日皮会誌, $83: 407,1973$. 


\section{第 9 回学術莱会 ポシ்ム}

昭和59年 8 月 3,4 日（金, 土）

ロイヤルNCB会館

\title{
諸臓器癌におけるリンパ節郭清法一 $\mathrm{C}$ 群
}

$\mathrm{S}-\mathrm{I}-25$

\section{外陰癌のリンパ節郭清法}

\author{
九州大学虐婦入科 \\ 场本直樹枟山敏㴊松隈敬太 \\ 嘉村钽治冎藤俊章松村真理子
}

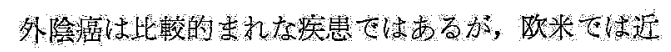

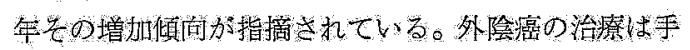

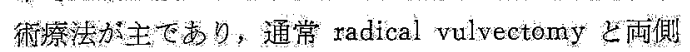

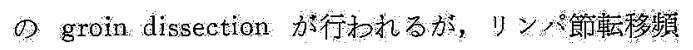

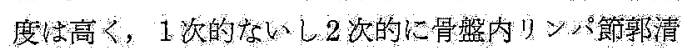

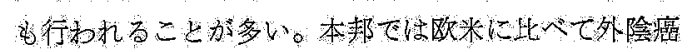

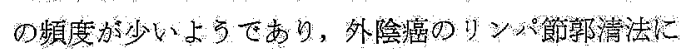

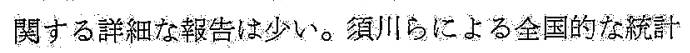
報告によると，本邦に打り外䧔后の治療は放射線療

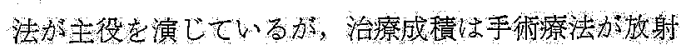

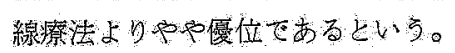

我及は1979 1983年の5年間に8 例の外险癌，2例

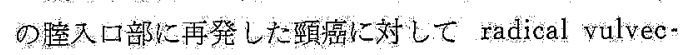

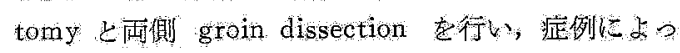

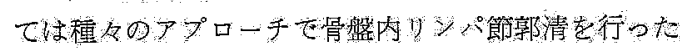

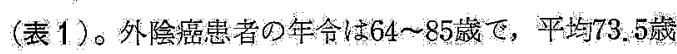

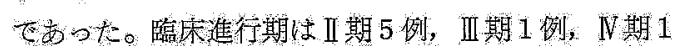

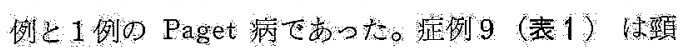

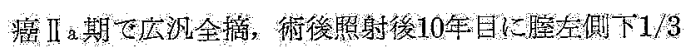

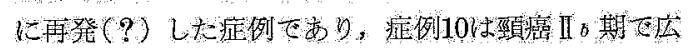

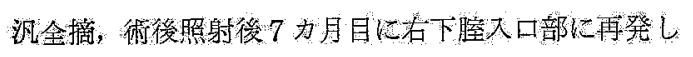

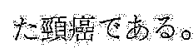

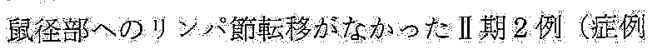
1，6)，卭期 1 例 (症例 7) foo Paget 病 1 例(症

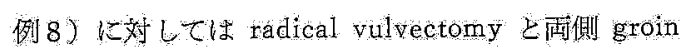

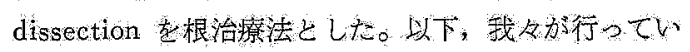

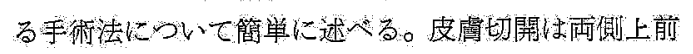

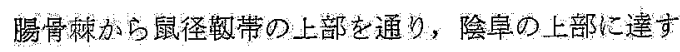

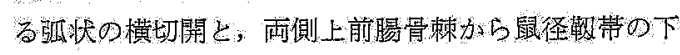

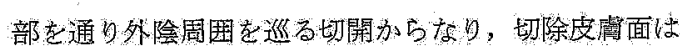
ねぼ鬼の頭の形をなる。

度切後，皮下組織者下腹部の上方\&飞 undermine

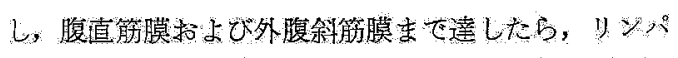

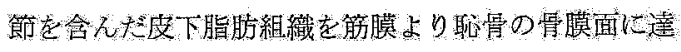

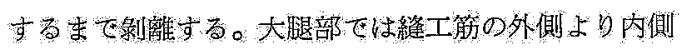

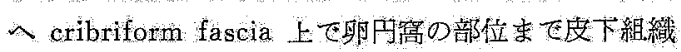

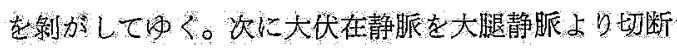
し $\subset$ femoral sheath 内に入り，大腿陻静脈周困の租

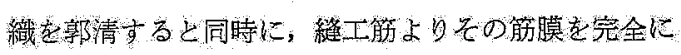

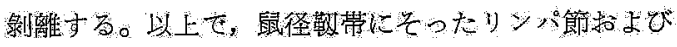
犬腿三角部内のりメ節が汪完全に郭清される。犬 腿静脈内上側の cloquet 節は別個に切除Lて紂織検查 人提此方。

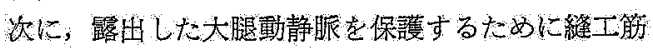

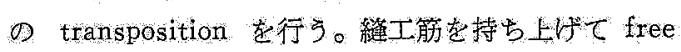
KL，上端の上前晹骨棘加 5 切断して内側风移動。

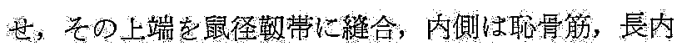

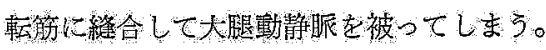

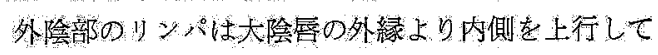

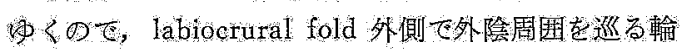

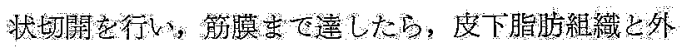

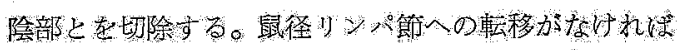

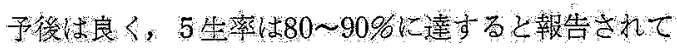
w。

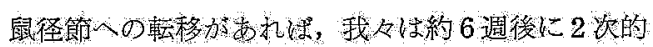

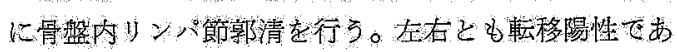

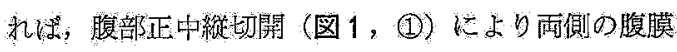

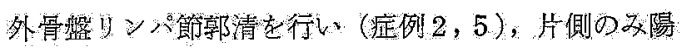

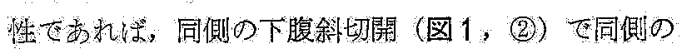

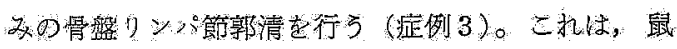

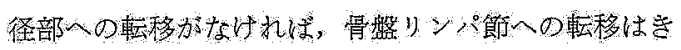

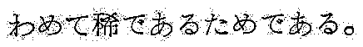

次に，頸癌などて骨盤部に放射線照射支受棫てい

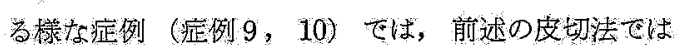


日本外科系連合学会誌 第12号

表 1 Radical Vulvectony and Bilateral Groin Dissection 施行症例 (1979-1983年, 九州大学産婦人科)

\begin{tabular}{|c|c|c|c|c|c|c|c|c|}
\hline 症 例 & 年令 & 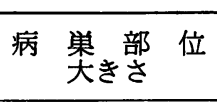 & 進行期 & 組織型 & 外陰切除時の術式 & 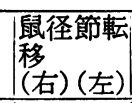 & 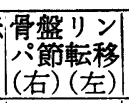 & 予 \\
\hline 1. F.N. & 64 & $\begin{array}{l}\text { 右大陰唇 } \\
2.5 \times 1.5 \mathrm{~cm} \\
\end{array}$ & II & 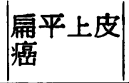 & $R V+B G D$ & $(-)(-)$ & & 61 力月, NE D \\
\hline 2. T.N. & 85 & $\begin{array}{r}\text { 右大小陰唇 } \\
4 \times 5 \mathrm{~cm}\end{array}$ & II & |㴜平上皮 & $R V+B G D$ & $(+)(+)$ & $(+)(+)$ & 3 力月, 他病死 \\
\hline 3. T. T. & 70 & $\begin{array}{c}\text { 右大陰唇 } \\
4 \times 5 \mathrm{~cm} \\
\end{array}$ & II & \begin{tabular}{|l|}
$\mid$ 腺癌 \\
Paget 病
\end{tabular} & $R \mathrm{~V}+\mathrm{B}$ G D & $(+)(-)$ & $(+)(-)$ & 17 力月, 癌死 \\
\hline 4. E.N. & 67 & $\begin{array}{l}\text { 右大陰唇 } \\
2.3 \times 3.8 \mathrm{~cm}\end{array}$ & II & |屚平上皮 & R V + B G D & $(+)(+)$ & $(-)(-)$ & 23力月, NE D \\
\hline 5. K. K. & 67 & $\begin{array}{l}\text { 両側大小陰唇, } \\
\text { 䐋, 尿道, 肛門, } \\
\text { 直腸, 鼠径節 }\end{array}$ & N & 扁平上皮 & 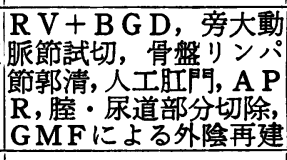 & $(+)(+)$ & $(t)(+)$ & 20力月, 他病死 \\
\hline 6. M. A. & 82 & $\begin{array}{c}\text { 右大陰唇 } \\
2 \times 3 \mathrm{~cm}\end{array}$ & II & \begin{tabular}{|l|}
$\mid$ 腺癌 \\
Paget 病
\end{tabular} & & $(-)(-)$ & & 21力月, NE D \\
\hline 7. H. T. & 78 & $\begin{array}{c}\text { 左大小陰唇, 䐮 } \\
6.5 \times 6.5 \mathrm{~cm}\end{array}$ & III & $\mid \begin{array}{l}\mid \text { 扁平上皮 } \\
\text { 虞 }\end{array}$ & 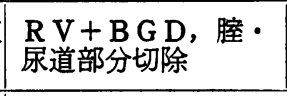 & $|(-)(-)|$ & & 16力月, NED \\
\hline 8. S.E. & 75 & 両側大小陰唇 & 0 & Paget病 & G D & $(-)(-)$ & & $\begin{array}{l}12 \text { 力, } \\
\text { Paget 病残存 }\end{array}$ \\
\hline 9. T.S. & 55 & $\begin{array}{c}\text { 左臸側壁下 } 1 / 3 \\
2.5 \times 2.5 \mathrm{~cm} \\
\end{array}$ & 頸癌再 & 扁平上皮 & \begin{tabular}{|l|}
$R V+B G D$, total \\
pelvic exenteration, \\
GMFによる外陰再 \\
建 \\
\end{tabular} & $(-)(-)$ & 広汎後 & 39 力月, 癌死 \\
\hline 10. $\mathrm{M}$. & 38 & $\begin{array}{c}\text { 右下腔入口部 } \\
4 \times 5 \mathrm{~cm}\end{array}$ & 頸癌再 & 㾫平上皮 & 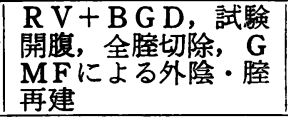 & $(-)(-)$ & 広汎後 & 35 力月, $\mathrm{N}$ E D \\
\hline
\end{tabular}

$\mathrm{RV}+\mathrm{BGD}$ : radical vulvectomy and bilateral groin dissection

APR : abdominoperineal resection

GMF : gracilis myocutaneous flap

NED : no evidence of disease

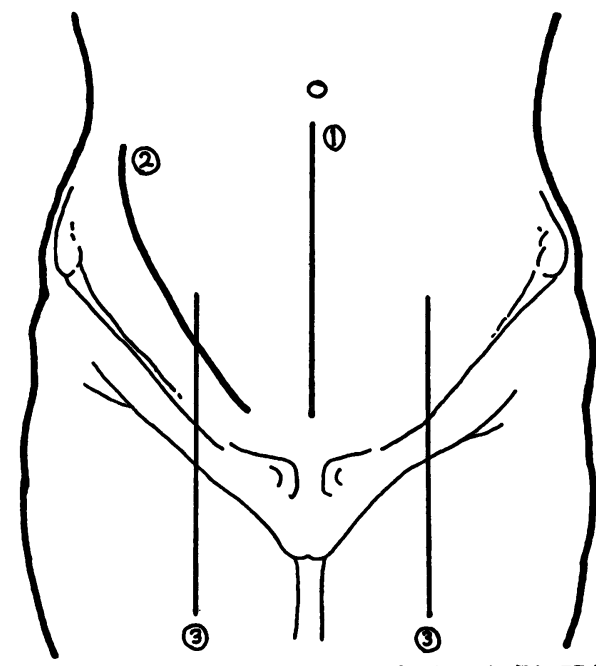

図 1 骨盤および鼠径リンパ節郭清の皮后切開線 wound breakdown が起ることが多いので, radical vulvectomy と groin dissection とを別々の皮切て 行った方が良い場合がある。この様な時には groin dissection は大腿正中より下腹部に達する縦切開（図 1，(3）を通して行う。

症例 5 は, 夫々 $7 \times 4 \mathrm{~cm}, 4 \times 2 \mathrm{~cm}$ 転移が左右の 鼠径節にあり, 外尿道口, 腟, 直腸粘膜に浸潤があっ た広汎な $\mathrm{N}$ 期外陰癌であった。この症例に対しては, 恥骨より臍上に達する正中縱切開て開腹，まず旁大動 脈節試切を行い凍結切片組織検査で転移がないことを 確誌した。そして，骨盤リンパ節郭清を行い， $\mathrm{S}$ 字状 結腸を切断，人工肛門を造設した。次に正中切開創か ら両側鼠径部にかけて皮下を undermine して, 両側 の groin dissection を行い, radical vulvectomy と 腔, 尿道の部分切除とを行った。更に, abdomino- 
第 9 回学術集会シンポジウム

perineal resection を行って, 広沉な外陰の欠損部に 開腹を必要とする外陰癌の手術には応用してよいのて 対しては両側の gracilis myocutaneous flap を用い はないかと思われる。

た再建術を行った。正中切開創を通しての groin di-

最近 5 年間の症例のみで少数であるが，1術者の ssection は本邦ては報告がないが, exposure も十分 に得られ，本症例では skin の breakdown もなく, philosophy のもとに行っている外陰癌のリンパ節郭 清法について述べた。 